\title{
ASPECTOS DO ENSINO DA CONTABILIDADE NOS ESTADOS UNIDOS
}

\author{
José Carlos Marion \\ DEPARTAMENTO DE CONTABILIDADE E ATUÁRIA \\ FACULDADE DE ECONOMIA, ADMINISTRAÇÃO E CONTABILIDADE - USP
}

\subsection{Essência do Trabalho}

\section{Introdução}

Quando nos propusemos a desenvolver um levantamento do estagio atual do Ensino da Contabilidade nos Estados Unidos tínhamos em mente que este ensino não e perfeito, mas que. certamente, diante da ausência de uma melhor alternativa, poder:a ser multo útil como parâmetro para comparação com o modelo brasileiro.

Não ficaríamos surpresos se em alguns pontos do atual ensino da Contabilidade no Brasil, ao se comparar com o modelo americano, tivermos vantagens por exemplo, ao meu ver, [nossa didática de ensino e nitidamente superior a americana. Todavia, isto não elimina a necessidade de uma avaliação global e profunda da maneira que estamos conduzindo este ensino, mesmo porque, sabemos que, se ha pontos fortes e ate elogiáveis, também existem falhas grotescas na estrutura de ensino contábil brasileiro que requerem pelo menos um questionamento imediato].

E lógico que esta proposta seria muito mais abrangente se pudéssemos incluir informações sobre o ensino da Contabilidade de outras regiões tais como alguns paises europeus, asiáticos etc. Aliado ao fato de ser quase impossível tais tipos de levantamento (principalmente diante da limitação de recursos), resta-nos a desculpa que de certa maneira, o modelo americano tem exercido alguma influência no ensino da Contabilidade em muitos paises bem conceituados neste aspecto (como, por exemplo, o caso da Itália, considerado o berço da Contabilidade).

Outro ponto fundamental a ser considerado é que a atual estrutura do ensino americano da Contabilidade tem sofrido severas criticas internas. Dois prestigiados documentos que abordam a necessidade de significativas mudanças no ensino da Contabilidade nos Estados Unidos (Comitê Bedford (08) e as seis maiores empresas de Auditoria (07)), parecem preferir uma revolução em vez de uma evolução na estrutura atual na formação dos Contadores.

Dai, nossa preocupação em considerar simultaneamente ao estudo do estagio atual do ensino da Contabilidade nos Estados Unidos as reivindicações de mudanças, bem como avaliar as principais mudanças propostas. Assim, estamos considerando o que e o ensino atualmente e o que deveria ser (conforme a opinião de alguns conceituados segmentos nos Estados Unidos), entendendo que esta abordagem dupla vem enriquecer sensivelmente este trabalho.

\section{Abrangência do Trabalho}

Entendemos que para melhor avaliar o Ensino da Contabilidade é fundamental conhecer o "ambiente" em que este ensino e desenvolvido.

Dessa forma, entendemos nossas considerações para pontos que estão direta ou indiretamente afetando o ensino da contabilidade ou, ainda, situações que melhor explicam o atual estagio deste ensino. 
Começamos o trabalho fazendo rápida análise do Sistema Educaclonal nos Estados Unidos, partindo do global e chegando no Departamento de Contabilidade.

Uma visão do quadro atual do profissional contábil nesse pais também se fez necessária, considerando as exigências para o exercido da profissão ate o mercado de trabalho.

Aspectos sobre o perfil do corpo docente, recursos disponíveis nas instituições de ensino, perfil dos estudantes e outros dados são considerados.

\subsection{Fontes de Dados}

Nosso "quartel general" foi o Departamento de Contabilidade da Business School da Universidade de Kansas em Lawrerice, estado de Kansas, no centro dos Estados Unidos.

Nosso trabalho foi desenvolvido com a ajuda dos professores da área contábil da divisão de Contabilidade da Universidade Kansas, onde estivemos sediados no período de agosto de 1990 a janeiro de 1992. Ainda que todos os professores contribuíssem, é digna de destaque a participação da professora Beverly Wilson e do diretor da divisão, professor Bruce Bublitz, que nos ajudaram inclusive nos primeiros contatos com universidades e diversas outras instituições.

A divisão de Contabilidade colocou à nossa disposição toda a infraestrutura da Business School para que este trabalho pudesse ser realizado. Foi nos concedido um office para as nossas instalaçõeS durante este período. Pudemos contar com um moderno centro computacional de uso dos estudantes além de uma sala especial com microcomputadores exclusivo para professores (quando necessário pudemos usar ainda o computer center da universidade que funciona 24 horas por dia e todos os dias do ano). Através dos microcomputadores pudemos nos comunicar com outras universidades, sem nenhum custo, via sistema bitnet. Tivemos acesso aos sistemas de Fax, ao centro de reprodução (cópias e impressos), à biblioteca e a outros recursos desta escola durante todo o tempo de nossa permanência.

Tivemos oportunidade de assistir a aulas com quase todos os professores da Divisão de Contabilidade no sentido de observação pedagógica, conteúdo programático e metodologia de ensino, tais como:

\section{Fall Semester/90}

Managerial Accounting Information - Bus 805 - Profa. Beverlv

Wilson

Financial Accounting 1- Bus :240 - Prof. Lyan Cravens

\section{Spring Semester/91}

Intermediate Accounting - BUS 510 - Prot Tim Shaftel Financil Accounting 3 - BUS $6 I O$ Prof. Bill Salatka Advanced Accounting Problems - SUS 751 - Prof. Bruce Bublitz.Worsknop in Accounting - BUS 928 - Profa. Rajendra Srivastava Cost Accounting - BUS 241/477 Prof. Beverley Wilson

\section{Fall Semester/91}

Financial Accounting Information - Bus 803 - Prof Betsy Goss Workshop in Accounting Bus 928 - Profa. Rajendra SrivastaVa 
É Lógico que para um trabalho com esta proposta não poderíamos estar ligados a uma única instituição de ensino, por melhor que ela fosse. Por isso, através de visitas e consultas junto a outras importantes universidades, de participação em congressos, de contatos com órgãos da classe contábil, de publicações de revistas e boletins e de outras fontes bibliográficas, pudemos reunir um material no mínimo, ao nosso ver, razoável, para estruturar este trabalho.

Ainda no estado de Kansas tivemos a contribuição da Universidade Estadual de Kansas situada em Manhattan, através do professor John Schlender do Departamento de Economia Agrícola.

Nossa consulta abrangeu um total de 50 universidades americanas mas, as que prestaram efetiva colaboração, além das universidades de Kansas (Kansas University e Kansas State University), foram: Brigham Young University, Arizona State University, Walden University, University of Missouri-Kansas City, University of Oklahoma, California State University, file University of Mississippi, University of Arkansas, University of Minnesota, Florida International University of Mercel University, The University of lowa, University of Montana, Missouri State University, Illinois State University, central Michigan University, Cornel University, The University of Hawaii, Utah State University, The University of Connecticut, University of Illinois. University of Massachusetts, University of Texas, University of Southern California, University of Idaho.

No que tange aos contatos com empresas de auditoria tivemos a contribuição de uma empresa regional "Kennedy and Coe-CPA", que abrange os estados de Kansas, Oklahoma, Cobrado e Nebraska, através do seu diretor R. Michael Beatty, que nos proporcionou importantes informações e obtivemos importantes materiais das seis maiores empresas de auditoria(Big six), como pode ser visto na bibliografia.

Em termos de contato com professores internacionais que visitaram a Business School/Divisão de Contabilidade da Universidade de Kansas durante a nossa estada, destacamos principalmente uma entrevista com o Prof. Bhabatosh Banerjee, da Universidade de Calcutá, Índia, que e autor de diversos livros e trabalhos sobre o ensino da Contabilidade. Tivemos ainda contato com o Prof. Àlexander Filatov Plekhanov, do Instituto Nacional de Economia de Moscou, especialista em pequenos negócios na forma de cooperativa. Em 1992, a Universidade de Kansas recebeu, na qualidade de professor visitante, o Prof. Nirihito Tanaka, da área de negócios e economia internacional da Universidade de Kanagawa, Japão.

Através de freqüentes seminários realizados pela Divisão de Contabilidade da Universidade de Kansas, pudemos ter contatos com outros professores americanos, de diversos estados, que de forma direta ou indireta trouxeram alguma contribuição para o nosso trabalho. Só para citar alguns exemplos destes seminários, tivemos: Prof. Ronald H. Coase, com trabalhos na área contábil, professor emérito de Economia e Direito da Universidade de Chicago e ganhador do prêmio Nobel de Economia em 1991; Prof. Theodore Souqiannis, da Universidade de Illinois; Prof. Wesley Andrew, da Universidade da Florida/Atlântico, e dezenas de outros.

Participamos de duas importantes conferenciais/congressos. Uma a nível nacional, realizada em agosto de 1991, em Nashville, Tennessee, da "Americafl Accounting AssociatiOfl", encontro anual. A outra, a nível regional, voltada especificamente para a educação contábil, realizada em janeiro de 1992 em Lawrence, Kansas - com o titulo de "KSCPA Accounting Educators Conference (com experiências trazidas da Universidade do Sul da Califórnia, da Universidade Estadual do Arizona e da Universidade de Notre Dame)".

Não poderíamos deixar de destacar o papel relevante das bibliotecas da universidade em que estivemos sediados, como a da Escola de Negócios (já citada), da Faculdade de Direito, e principalmente das "Science" e "Watson" (as duas principais bibliotecas gerais do campus da Universidade de Kansas). Os recursos que estão disponíveis nestas duas bibliotecas e a agilidade nas operações entre bibliotecas para qualquer tipo de material não localizado no campus, são surpreendentes Através destas duas bibliotecas gerais tivemos acesso às demais bibliotecas desejadas tanto nos Estados Unidos como em outros paises.

Caderno de Estudos nº7, São Paulo, FIPECAFI - Outubro/1992 
Adicionamos a tudo isto ainda importantes informações que tivemos através da assinatura por um ano (em conjunto com o "Wall Street Journal") do "The Educational Service Bureau - Dow Jones \& Co. Inc.", estando incluso neste pacote educacional "The Wall Street Journal Educational Edition; How Professors Use The Wall Street Journal; Dow Jones Averages: A Non-Professionals Guide; The Best of Barron's; How to Read Stock Market Quotations; e How Professors Use Barron's in the classroom".

Participamos também do "AT\&T Collegiate Investment abrangendo o período de novembro de 1991 a 28 de fevereiro de 1992. Nossa participação neste jogo de bolsa de valores foi na categoria de educador universitário".

Diversas editoras americanas e empresas de "softwares" também cooperaram com este trabalho através de fornecimentos de livros, textos, material didático, "softwares", manuais etc. Entre as que enviaram estes materiais como cortesia para a nossa analise, destacamos principalmente: Prentice-Hall, Irwin, Jai Press Inc. South-Western Publishing Co., Harvard Business School Press, Dame Publications Inc., McGraw Kill e outras citadas nas paginas deste trabalho.

Neste período ainda nos associamos a A.merican Account:ing Association tendo acesso a importante fonte de dados na área deste trabalho, além de contarmos com as publicações desta associação: The Accounting Review, Accounting Horizons e Issues In Accounting Education e ainda o Accounting Education News.

Outras fontes consultadas não estão relacionadas neste segmento, pois quase todas elas são citadas no decorrer do trabalho e/ou na bibliografia no final deste.

\section{Estudantes Internacionais}

No final da ultima década havia em torno de 400.000 estudantes estrangeiros nos Estados Unidos.

Aproximadamente $70 \%$ desses estudantes eram de sexo masculino: em media $80 \%$ deles eram solteiros; o maior grupo de estudantes vinha da Ásia. Numa pesquisa realizada na segunda metade da ultima década havia 22.590 estudantes de Taiwan; 21.720 da Malásia; 18.270 da Nigéria: 16.430 da Coréia; 15.370 do Canadá; 14.610 da Índia: 13. 160 do Japão; 10.290 da Venezuela; 10.130 de Hong Konq; 10.100 da China; Etc.

Já em meados de 1992 havia 407.530 estudantes de 193 paises (54), sendo que a China liderava com $9,7 \%$ deste total, seguida pelo Japão (9\%), Taiwan (8,2\%), Índia (7,1\%), Coréia (5,7\%), Canadá $(4,5 \%)$, Malásia (3,3\%), Hong Kong (3,1\%) etc.

Atualmente há mais de 3.500 instituições a disposição nos Estados Unidos entre faculdade e universidade. O "College Board" (c43 Box 886- NY - NY 10101) oferece um catálogo que indica os campos de estudos nos Estados Unidos e as respectivas instituições de ensino para estudante internacional fazer sua opção. Atualmente há, nesse pais em torno de 5.000 organizações que oferecem Bolsa de Estudo e/ou atividade de intercâmbio para estudantes internacionais (14)

Engenharia e o mais popular campo de estudo entre os estudantes internacionais (75,370 alunos), seguidos por Administração de Negócios - "Bussines School", onde esta incluído o curso de Contabilidade com 64.930 estudantes. Matemática Computação e Ciência da Informação vêm em terceiro lugar, seguidos por Medicina e Ciências Sociais.

Desses estudantes internacionais, $65 \%$ freqüentam instituições publicas que são mais baratas e $35 \%$ instituições privadas cujo custo para os estudantes Unidos é maior.

Caderno de Estudos n07, São Paulo, FIPECAFI - Outubro/1992 


\section{Sistema Educacional nos Estados Unidos}

Curso superior nos Estados Unidos é um grande negocio, atingindo anualmente U\$\$100 bilhões que representam $2,7 \%$ do produto nacional bruto. Nenhuma outra nação chega tão alto (56) 156 universidades; 1.953 faculdades; 1.378 faculdades de dois anos; 793.000 professores empregados; 14 milhões de estudantes; $60 \%$ dos que terminam o colegial

(54) freqüentam faculdade (Alemanha $=30 \%$, França $=28 \%$, Inglaterra $=20 \%$ e Japão $=37 \%$ )

\subsection{Cursos de Graduação}

Apos 12 anos de estudo o estudante obterá seu primeiro diploma, ou seja, do High School (correspondente ao nosso colegial ou segundo qrau) Em seguida, o estudante poderá optar por um curso superior de curta duração - Faculdade/Junior (Community College) por dois anos, ou um curso de graduação em instituição de quatro anos.

No curso de dois anos o estudante poderá optar por um curso de pré-profissionalização (engenharia, administração e negócios, educação) continuando seus estudos numa Faculdade de quatro anos, ou alcançar um grau terminal numa escola técnica. O grau obtido na Faculdade/Junior é chamado de Associado.

As instituições (Faculdade/Universidade) com cursos de graduação (chamado de underqraduate) de quatro anos formam bacharéis que deverão estudar em período integral para obter seu grau de: B . A. (Bachelor of Arts); B.S. (Bachelor of Science.); B.F.A. (Bachelor of Fine Arts); B. Ed. (Bacherol of Education) e B. B.A. (Bachelor of Bossiness Administration) que abrange a area contábil.

No curso de quatro anos os estudantes recebem uma denominação para cada ano escolar: $1^{\circ}$ ano Freshman; 2ํano - Sophomore; 3ํano - Junior; 4ํano - Senior.

Cada estado nos Estados Unidos tem universidade(s) para atender a seus residentes a um custo menor. Em grande parte seus recursos são propiciados pelo estado ou União o aluno paga outra parte. Estas são as universidades publicas com custos reduzidos para os estudantes e custos menores que as universidades particulares para os estudantes de outros estados ou estrangeiros.

Todavia, os estados possuem suas universidades ou instituições privadas estabelecidas por organizações privadas ou grupos religiosos. Ainda que normalmente haja outras fontes contribuindo para 0 orçamento destas Instituições, elas sempre são mais onerosas para os estudantes.

\subsection{Pós-Graduação}

Para obtenção do titulo de mestre há programas que exigem, alem de cursos com as disciplinas do mestrado com duração não inferior a dois anos, um projeto de pesquisa ou tese, um exame compreensivo e/ou proficiência em uma ou mais línguas. 
Os graus de mestres mais conhecidos são: M.A. (Master of Arts); 14.8. (Master of Science); e os programas profissionais, como o M.B.A. (Master of Business Administration), que inclui a área Contábil, com dois anos de duração, geralmente em período integral.

Normalmente, os mestrados em Contabilidade têm programas que enfatizam os graduados em Contabilidade e os graduados em áreas não contábeis, havendo uma significativa diferenciação de currículo e conteúdo.

O grau de doutor, ou Ph.D. (Doctor of Philosophy], e o mais alto concedido nas universidades americanas para os estudantes que completam todas as exigências do programa em :ermos de estudos avançados e pesquisas.

As exigências para o Ph.D. variam entre os programas das universidades. Em geral, o estudante deve completar dois anos de curso, além do grau de mestre, passar no exame de qualificação que mede seu conhecimento geral do campo de estudo e desenvolver uma pesquisa original avançada que culminara com a sua dissertação (no Brasil normalmente chamamos de dissertação para o mestrado e tese para o doutoramento; nos Estados Unidos normalmente e o inverso). O grau de doutor e obtido em média de dois a cinco anos. Nas escolas de Administração e Negócios (Business School) um programa completo de doutoramento dura em torno de cinco anos. Assim, e comum observar programas de doutoramento com 30 alunos, sendo admitido 6 novos alunos por ano.

Alguns programas de doutoramento exigem que o candidato, após ter feito seu mestrado, tenha três ou mais anos de experiência profissional para, a partir dai, ser admitido.

\subsection{Sistemas de Notas}

Há alguns tipos de sistemas de notas usados pelas universidades para avaliar o desempenho dos estudantes. Dois sistemas habitualmente usados são em letras e notas em percentagens

\begin{tabular}{|c|c|c|c|}
\hline Notas e Letras & \multicolumn{2}{|c|}{ Percentagens } & Significados \\
\hline$A$ & 90 & 100 & Excelente \\
\hline B & 80 & 89 & Bom \\
\hline C & 70 & 79 & Média \\
\hline $\mathrm{D}$ & 60 & 69 & Abaixo de Média \\
\hline $\mathrm{F}$ & \multicolumn{2}{|c|}{ Abaixo de 60} & Deficiente \\
\hline l & \multicolumn{2}{|c|}{--} & Incompleto \\
\hline
\end{tabular}

O que e muito importante nos Estados Unidos e a computação da media de pontos (GPA = Grade Point Àverage), no qual o aluno atinge no Maximo quatro pontos. Esta media e calculada com base no curso inteiro e ponderada de acordo com o número de credito por disciplina. Por exemplo, num primeiro semestre num curso em Business o GPA de um aluno seria calculado da seguinte maneira: 


\begin{tabular}{lccc|}
\hline Curso & Crédito & Notas & Pontos \\
\hline Inglês & 3 & $\mathrm{C}[=2]$ & 6 \\
Contabilidade & 4 & $\mathrm{~B}[=3]$ & 12 \\
Adminlstração & 4 & $\mathrm{~A}[=4]$ & 16 \\
Psicologia & 3 & $\mathrm{~B}[=3]$ & 9 \\
Economia & 3 & $\mathrm{~A}[=4]$ & $\underline{12}$ \\
& $\underline{17}$ & & \\
& & &
\end{tabular}

O GPA e uma das principais variáveis quando a empresa americana quer recrutar seus funcionários. Dessa forma, ha uma preocupação excessiva dos estudantes no sentido de obter boas notas.

\subsection{Calendário Acadêmico} académicos:

O ano letivo é de aproximadamente nove meses. Ha básicamente tres tipos de penados

Em forma de semestre, varia de 14 a 16 semanas de duração. O primeiro semestre (o ano letivo) começa em agosto/Setembro, terminando em dezembro. Este semestre, que inicia o ano letivo, e conhecido como Fall ou outono; o segundo semestre vai de janeiro a maio e conhecido como Spring ou primavera.

Muitas universidades oferecem ainda os cursos de verão (Summer Sessions). As disciplinas são oferecidas em junho e julho, num total de cinco a seis semanas. Os estudantes São normalmente impedidos de cursar mais de duas disciplinas porque elas são ministradas de forma intensiva (correspondendo assim a um semestre) Inscrever-se nos cursos de verão e uma excelente maneira para os estudantes estrangeiros reduzirem seu tempo de permanência nos Estados Unidos.

\subsection{Escolha da Universidade}

Muitas variáveis são importantes na escolha da universidade pelo estudante estrangeiro. Além do gasto com a universidade, como vimos em termos de publica e particular, o custo de vida em cada região e outra variável indispensável na opção.

Uma pesquisa feita pela American Chamber of Commerce Researches Association Intercity/cost of Living Index (25) mostra as diferenças regionais do Custo de Vida nos Estados Unidos no inicio desta década. Iniciando com um índice médio de Custo de Vida igual a 100, observamos significativas variações. Por exemplo, os lugares de maior Custo de Vida são:

\section{Califórnia:}

Los Angeles

124,8

Oranqe County $\quad 128,8$

San Diego $\quad 131,2$ 


\section{Connecticut:}

Merideri

129,1

New London

124,9

New York:

Nassau/Guffolk

153,7

Alguns lugares de menor custo de vida são:

$\underline{\text { Utah: }}$

Provo/Orem

90,5

Salt Lake City

92,0

Mississippi

Hattiesburg

91,2

South Dakota:

Sioux Falls

91,2

Outros estados que a pesquisa mostra com baixo Custo de Vida são: Tennessee, West Virginia, Missouri, Nebraska North Dakota, Kentucky, Arkansas, tendo índices próximos de 95.

Ha estados, todavia, que apresentam signiflcativas variações de uma cidade para outra. Por exemplo, na Pennsylvania, Philadelphia, apresenta um índice de 128,0 enquanto Sharon, no mesmo estado, tem um índice igual de 95,6. No próprio estado de New York, ha lugares como Binghamton e Syracuse com índice de 1\%, ainda que acima da média, mas baixo perto dos locais acima descrlto onde o índice chega a 153,7 .

Assim se um estudante tivesse uma bolsa de U\$\$1.000,00 para suas despesas em Oram(UTHA precisaría de U\$ 1.700,00 para ter o mesmo padrão de vida no condado de Nassau (NY). Por ai, pode-se observar como esta variável do Custo de Vida e fundamental.

\subsection{Business School}

As Escolas da Administração e Negócios nos Estados Unidos, ao contrario do Brasil, normalmente não incluem o curso de Economia (Ciências Sociais), concentrando-se basicamente na área de Administração e Contabilidade.

Normalmente, o estudante escolhe sua área de especialização (Major - [mataria de maior interesse ou interesse principal] no terceiro ano de faculdade. Assim, por exemplo, o estudante entra ria Business Scbool concentrando seus estudos na Contabilidade para obter o seu grau de B.B.A).

Caderno de Estudos n07, São Paulo, FIPECAFI - Outubro/1992 
$\mathrm{Na}$ área de Business ha diversas opções de concentração: Administração e Comercio, Contabilidade, Marketing, Propaganda e Publicidade, Administração de Negócios, Finanças e Bancos, Administração de Hotel e Restaurante, Administração, Imobiliária, Imobiliária,Vendas,Transportes, Secretariado, Administração de Pessoal etc.

No primeiro semestre de 1991, diretores de aproximadamente 700 Escolas de Administração e Negócios se reuniram (15) para planejar mudanças nos programas desenvolvidos nestas escolas.

De aproximadamente 300 instituições em 1976, os Estados Unidos contam hoje com praticamente 700 escolas com programas na arca de Business. Estas escolas reconhecem que o seu longo penado de ascendência pode estar terminando, (15) mesmo porque tem caído o numero de inscritos a cada semestre.

O objetivo das mudanças propostas e melhor adequar o futuro profissional as rápidas mudanças do mercado, principalmente porquE o mundo empresarial americano tem reivindicado uma nova postura do ensino de Negócios. No decorrer da nossa exposição, faremos mençõeS a algumas propostas de mudança para a área contábil, que e um dos pontos importantes no nosso ver.

\subsection{Escola e Departamento de Contabilidade}

\subsubsection{Escola de contabilidade}

Em quase sua totalidade o departamento de Contabilidade faz parte da Business School. Todavia, ha as Escolas de Contabilidade e, em nossa pesquisa, tivemos contato com a pioneira, ou seja, a Escola de Contabilidade da Universidade de Mississippi. Esta escola, além do curso de graduação, oferece o mestrado em Contabilidade, bem como o único Ph.D em Contabilidade nos Estados Unidos credenciados por uma Escola de Contabilidade \{Schcool of Acoountancy\}, em contraste com os outros Ph.D nas Business School com concentração em Contabilidade.

A Escola de Contabilidade da Universidade do Mississippi (32) foi a primeira a obter credenciamento como escola de Contabilidade independente, em maio de 1983, tanto para a graduação como para a pós-graduação. Hoje há diversas delas e já existe nos Estados Unidos a Federação das Escolas de Contabilidade.

\subsubsection{Departamento de Contabilidade e Conselho Consultivo}

Uma experiência interessante observada em diversos departamentos ou divisão de Contabilidade (nos Estados Unidos, tanto divisão como departamento e a mesma coisa) e a constituição de um Conselho Consultivo para assistir a Divisão de Contabilidade que normalmente se reúne duas vezes ao ano com o corpo docente. Este conselho, em alguns casos, constituído por 20 membros envolvidos no mundo de negócios, além de ser um importante canal de aluda financeira, tem como objetivos:

- Propiciar um canal de comunicação entre os professores da Divisão de Contabilidade e a comunidade profissional.

- Proporcionar uma fonte na qual professores e o chefe do Departamento de Contabilidade possam buscar e receber assistência relacionada ao envolvimento dos docentes na profissão e na comunidade, ao 
recrutamento de estudantes de Contabilidade, ao necessário desenvolvimento do currículo para estar em harmonia com o dinâmico mundo dos negócios e outros assuntos.

- Proporcionar aos docentes de Contabilidade um fórum para discutir seus programas de pesquisa e as implicações para o exercício profissional.

- Comunicar aos professores de Contabilidade as preocupações e os problemas contábeis atuais que merecem um estudo acadêmico.

- Auxillar no desenvolvimento de planos para obter apoio financeiro para as necessidades vitais não supridas através do estado, tais como projetos de pesquisa, suplementação de salário para os docentes, biblioteca, bolsa a alunos e equipamentos;

- Revisar as gastos dos fundos privados em favor do Departamento de Contabilidade e assistir o chefe do departamento nos futuros orçamentos.

- Promover uma imagem positiva dos estudantes, docentes e programas do Departamento de Contabilidade na comunidade profissional e no publico em geral.

- Ser uma voz constante de divulgação fora da área universitária, das necessidades políticas e atividades do departamento.

- Auxiliar os docentes na busca das alternativas que os capacitarão para a obtenção de relevantes experiências pratica necessárias para a qualificação deles e para satisfazer as exigências estabelecidas pela American Assembly of Collegiate Schools of Business para credenciamento dos programas de Contabilidade.

- Assistir os docentes e a administração no recrutamento e manutenção de estudantes e professores do mais alto nível etc.

\subsubsection{Suporte Financeiro ao Departamento de Contabilidade}

Um fato curioso em relação aos Departamentos de Contabilidade nas universidades americanas é o apoio irrestrito das firmas de Contabilidade ou empresas de Auditoria como nos chamamos. Normalmente sócios dessas empresas de auditoria locais e das grandes empresas de auditoria estão envolvidos nos Conselhos Consultivos referidos.

Além de essas empresas citadas conseguirem suporte financeiro aos Departamentos de Contabilidade junto aos seus clientes, elas mesmas [empresas de auditoria] contribuem com generosas doações no sentido de aperfeiçoar o ensino da Contabilidade.

Por exemplo, o Departamento de Contabilidade da School of Business da Universidade de Kansas divulgou (26) algumas doações (anuais) recebidas em 1991 destas empresas:

Arthur Anderson Worldwide Organization doou U\$\$200.000 para aperfeiçoamento da parte computacional, além de doar $\mathrm{U} \$ 23.00$ para compra de novos computadores.

- $\quad$ Ernest \& Young aumentou sua doação anual para USS 825.000, destinados basicamente para pesquisas de docentes do departamento. Ressalte-se que o departamento em analise dispõe apenas de oito professores, todos em período integral; 
- $\quad$ A KPMG Peat Marwick,por sua vez, aumentou suas doações de 175.000 , para US $\$ 500.000$ visando aperfeiçoamento na área contábil.

Outra empresa menor, só para exemplificar, a Baird, Kurtz \& Dobson, contribuiu com U\$ 50.000 para bolsas a docentes e estudantes.

Essas empresas quando contribuem com as Business School entendem que a doação monetária e um investimento, pois elas mesmas serão beneficiadas no futuro com melhores profissionais em seus quadros de funcionários.

Além das empresas de auditoria e outras empresas que contribuem para o departamento de contabilidade, encontram-se listas de doadores particulares que apóiam o programa de Contabilidade. Ainda a titulo de exemplo, a universidade em análise (26) contou com centenas desses doadores, como segue abaixo:

- Doadores individuais acima de $\bigcup \$ \$ 5.000$ cada................................10 pessoas;

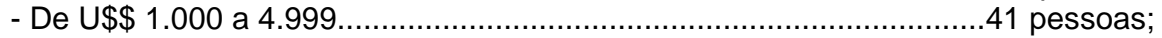

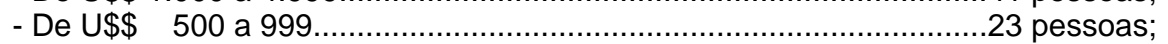

- De U\$ 300 a 499.................................................................16 pessoas;

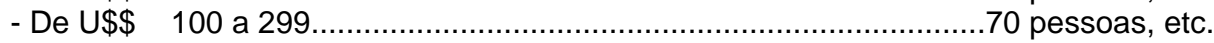

Há outras listas de contribuições voluntárias em outras categorias (sócios de empresas de auditorias, sêniors, patrocinadores, investidores, amigos, pequenas empresas etc) . Esta realidade, em proporções muito maiores em diversos casos, se estende a todos os departamentos de Contabilidade das universidades americanas.

Ressalta-se que estas contribuições têm dado equilíbrio financeiro aos departamentos de Contabilidade e as Business School. Todavia, este equilíbrio não é peculiar as demais escolas, tanto e verdade que o ensino superior nos Estados Unidos atravessa sérios problemas na área financeira. Em recente levantamento no inicio de 1992 (47) vimos, depois de 18 anos de incrível crescimento, que um bom numero de universidades americanas esta tendo reais dificuldades financeiras, deixando de investir e ate reduzindo suas atividades. tudo isto principalmente em virtude da recessão, com as reduções da receita de impostos e aumento das despesas.

Como exemplos, a Yale University teve um deficit de U\$\$ 8.8 milhões no ano letivo 91/92, que em pouco tempo chegara, conforme previsões, a $\bigcup \$ \$ 50,0$ milhões. Em virtude disso, depois de cortes sensíveis, esta havendo a extinção de dois departamentos (lingüística e pesquisa operacional), unificação de três departamentos de engenharia, redução nas atividades esportivas, redução do quadro de funcionários etc. Cortes semelhantes estão acontecendo em Stanford com reduções de U\$\$ 43,0 milhões nos próximos dois anos. A Columbia University enfrenta U\$\$ 50,0 milhões de "deficit" O estado da Califórnia, considerado o mais rico, cortou nesse último ano letivo U\$\$ 369 milhões da ajuda para o ensino superior do estado. A University of Califórnia, Berkeley, cortou 163 professores em regime integral e parcial e aumentou a anuidade em $40 \%$. Prevê-se que a anuidade para os estudantes da State University New York pode dobrar nos próximos dois anos. Algumas Universidades já aumentaram consideravelmente a anuidade para os estudantes, como a Oreqon. State University - 36\%, the University of Maine - 15,6\%, a de Mlssissippi - $25 \%$ e outras mais.

\subsection{Admissão na Bussiness School}

Caderno de Estudos nº7, São Paulo, FIPECAFI - Outubro/1992 


\section{Graduação}

As Business School selecionam candidatos que satisfaçam um mínimo de exigências. Os dois itens mais importantes são o total do GPÃ (Grade Point Average) - média de notas obtidas no High School (colegial) - e os pontos avançados no ACT (American College Test) ou no SÃT (Scholastic Aptitude Test). O ACT É o mais comum para a Business e é oferecido varias vezes no ano.

Cada Business Schooll tem um score mínimo que o candidato deve atingir, tanto no GPA como no exame ACT. Alem disso, há instituições que consideram adicionalmente fatores qualitativos para o processo de seleção e o GPA mínimo das disciplinas referentes à Administração cursadas no High Achool.

As escolas mais famosas exigem um score mais alto, o qual poucos alcançam.. As menos famosas exigem um total de pontos menor, de maneira tal que praticamente todos os candidatos são encaixados.

\section{Pós Graduação}

Para admissão no mestrado, de maneira geral, os critérios são dois: o primeiro baseando-se no desempenho no curso de graduação, considerado o GPA e o segundo, o candidato devera ser submetido ao exame GMTA (Graduate Management Admissions Test) administrado pelo Educational Test Servise (Princeton, New Jersey).. Assim como para a graduação, cada Businees School exige um numero mínimo de pontos para ser atingido pelo candidato, além de outras exigências, como duas cartas de recomendações de professores etc.

Normalmente, a admissão para o doutorado é baseada numa análise detalhada do potencial do candidato. Além de uma análise personalizada da formação/experiência do candidato, há instituições que exigem que o interessado freqüente, durante um ano, a disciplina Admissions Worksho para ser avaliado ao longo ao período pelo corpo docente e então, no final, do curso ser (ou não) admitido no doutorado. Este curso é desenvolvido em fins de semana alternados e permite ao docente avaliar o verdadeiro potencial do candidato.

A maioria das instituições de ensino exige que o candidato tenha o grau de mestre e três ou mais anos de experiência profissional para ser admitido no doutorado. Há casos excepcionais em que candidatos são admitidos sem o titulo de mestre, desde que o seu currículo demonstre um extraordinário desempenho e habilidade para o doutoramento.

\section{$4 \quad$ O Profissional Contábil}

\subsection{Campo de Trabalho}

Caderno de Estudos n07, São Paulo, FIPECAFI - Outubro/1992 
Nos Estados Unidos há três áreas distintas como campo de trabalho para o profissional contábil:

Contador Publico: e o campo da contabilidade que propicia o exercício de diversos serviços contábeis remunerados para clientes específicos. (Estes profissionais trabalham em firmas de Contabilidade Publica (firmas de auditoria) e possuem normalmente o Certificado de Contador publico, ou seja, o CPA (ceritíed public accountant). E uma licença, individual por estado, para praticar a Contabilidade publica apos atender um certo numero de exigências, entre elas um exame administrado e aplicado a nível nacional pelo American Institute of Certified Public Accountants - AICPA).

Contador de empresa privada: é o profissional contábil que trabalha como empregado de uma empresa privada. Ainda que não seja obrigatório o CPA (1/3 dos CPAs trabalham em empresa privada), há institutos que proporcionam certificado para que o contador seja reconhecido como experiente e perito na Contabilidade. Um desses órgãos e o Institute of Managemente Accounting (CMA) que oferece um programa que permite ao candidato obter um certificado. Este exame toma 2,5 dias, num total de 17,5 horas, abrangendo: economia, finanças, processamento de dados, relatórios internos e externos, princípios de administração, métodos quantitativos e contabilidade gerencial.

Contador da Empresa Governamental: é a área menos importante como campo de trabalho, todavia tem crescido muito nos últimos anos. A necessidade de avaliação financeira, relatórios e controles das diversas organizações e agências sem fins lucrativos têm sido evidenciada a cada dia. Esta necessidade alcança hospital, instituição de ensino, organizações religiosas, agências de caridade e outras ramificações dos governos local, estadual e federal. Pelo tato de existirem maiores pressões e exigências por relatórios contábeis e controles, estas instituições sem fins lucrativos necessitam de mais profissionais da contabilidade.

Há ainda uma corrente voltada para a especialização em Sistemas de Informações com base no computador, já que normalmente as empresas remuneram bem melhor estes profissionais, tanto as firmas de Contabilidade Publica, as empresas privadas e as governamentais.;

\subsection{Procura por Empregos ta Área Contábil}

Anualmente cerca de 50.000 estudantes recebem grau de Bacharel em Contabilidade nos Estados Unidos. Considerando a própria influência do mercado, o recém-formado, (conforme pesquisa realizada em McInnes e Sanders 10), busca os seguintes tipos de emprego:

Contador Publico $39,8 \%$

Empresas Privadas/Industriais................................................30,0\%

Empresa Governamental................................................... $7,4 \%$

Continuidade em estudos avançados.....................................6,5\%

Outros.............................................................................. 16,

Em termos de pós-graduação a procura se acentua para o Contador Publico, como apresentamos na tabela abaixo (10)

Contador Publico $.54,2 \%$

Empresas Privadas/Industrias. $26,9 \%$

Caderno de Estudos nº7, São Paulo, FIPECAFI - Outubro/1992 


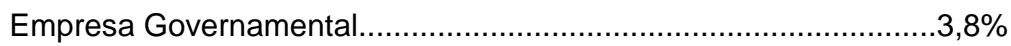

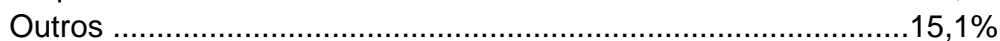

\subsection{Aspectos sobre o Certificado de Contador Público (CPA)}

O AICPA (American Institute Certified Public Accountants) e a organização nacional dos contadores públicos americanos. O instituto possui hoje 282.000 membros (CPA) que praticam a Contabilidade publica, ou estão vinculados em empresas privadas, no governo ou na área educacional. $O$ AICPA, além de proporcionar exames para credenciar contadores públicos, desenvolve padrões de auditoria, defende o código profissional de ética, propicia ao profissional a educação continuada e contribui com pareceres para o governo e setor privado no corpo de normas nas áreas tais como normas contábeis, impostos e bancos.

As exigências em relação à formação escolar e experiência para licenciar o profissional com CPA normalmente variam de estado para estado, ainda que o exame seja uniforme. Na Califórnia, por exemplo, além de ser submetido ao exame no AICPA, o candidato deverá ter o grau de bacharel e dois anos de experiência comprovada para se tornar um CPA. Há estados que exigem o mestrado. No estado de Kansas o governo decretou que, a partir de janeiro de 1977, para obter o CPA será exigido um mínimo de 150 horasdisciplina/semestre (atualmente e de 120 horas). Significa que se cada disciplina e ministrada três horas por semana, haverá necessidade de no mínimo 50 disciplinas, sendo que nesta condição um curso será desenvolvido em não nenos de 5 anos. Na Universidade de Kansas, por exemplo, para atender esta exigência de 150 horas, o candidato terá de fazer o mestrado. Ha outros estados ainda que exigem dois ou três anos de pratica em firmas de Contabilidade Publica. Ha ainda estados que não exigem o bacharelado, mas, por outro lado, o candidato tem de demonstrar experiência em Contabilidade Publica. Esta experiência normalmente e medida em anos de trabalho no estado de Nova York, por exemplo, (e exigido 15 anos de experiência)

As firmas de Contabilidade Publica ou empresas de auditoria como nos chamamos, proporcionam normalmente serviços de auditoria, consultoria, tributação e de contabilidade propriamente dito. [Nos Estados Unidos são encontradas pequenas firmas podendo ser individual], ate as multinacionais com mais de dois mil sócios. Até recentemente havia oito firmas de contabilidade multinacional, mas como em 1989 houve algumas fusões, o numero foi reduzido para seis (big six), por ordem de faturamento:

1) Arthur Andersen \& Co

2) Ernest \& Young

3) Deloitte \& Touche
4) KPMG Peat Marwick

5) Coopers \& Librand

6) Price Waterhouse

Para se obter este certificado - CPA, normalmente se requer grande dedicação por parte do candidato. O exame, composto de 4 partes, toma 19,5 horas, em 2,5 dias, e abrange: pratica contábil, auditoria, teoria contábil e legislação empresarial.

Cada ano, cerca de 140.000 candidatos se submetem ao exame para obter este certificado. A estatística não e alentadora: somente de $10 \%$ a $14 \%$ dos candidatos que se inscrevem pela primeira vez são bem sucedidos. De $80 \%$ a $90 \%$ dos candidatos considerados sérios, que se preparam com grande dedicação, estudando "duro", passam no exame CPA dentro de três anos da sua primeira tentativa.

Todavia, os analistas não culpam o ensino contábil por estes dados aparentemente desanimadores, mas a uma preparação inadequada dos candidatos (mesmo porque a maioria das instituições de ensino não 
da a ênfase maior para o exame (CPA), mas na formação profissional conforme a ótica de cada universidade), talvez, pudéssemos comparar, em um nível diferente, o ensino profissionalizante no Brasil que dá ênfase a especialidade que o estudante ira se formar e não ao vestibular. Assim, no ranking das melhores universidades americanas, não se pondera o índice de aprovação no exame do OPA.

\subsection{Aspectos sobre o certificado do Contador (CMA)}

A NAA (National Association of Accountants) foi fundada em 1919 e atualmente possui 93.000 contadores associados. Esta organização em contribuído para expandir o conhecimento e a profissionalização de pessoas especialmente interessadas em Contabilidade de Custo. Hoje a NAA não abrange apenas a Contabilidade Financeira, mas também Administração Financeira.

A NAA, além dos seus diversos objetivos. propicia exames para credenciar profissionais contábeis concedendo um certificado (não obrigatório) de contador (CMA) para os aprovados, assegurando este certificado para aqueles que satisfaçam suas exigências de educação continuada. Para obter este certificado, os candidatos devem completar quatro passos:

- Ser admitido para o exame CMA

- Passar nas 4 partes do exame dentro de um período de 3 anos

- Satisfazer as exigências do CMA

- Obedecer aos padrões de conduta de ética estabelecidos pelo NAA

Para a manutenção deste certificado é necessário comprovar sua competência através de programas de educação continuada: no mínimo 30 horas de curso por ano (90 horas a cada 3 anos) considerando pronunciamentos técnicos e artigos publicados.

Uma pesquisa salarial realizada pelo NAA (17) junto a 1172 profissionais contábeis com menos de $\underline{3}$ anos de trabalho na área contábil mostra a importância da obtenção de certificados profissionais:

$\underline{\text { Qualificação } \quad \text { Média: Total de salário anual }}$

Profissionais sem certificados ................................................... $\$ \$ 29.970$

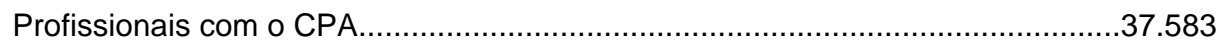

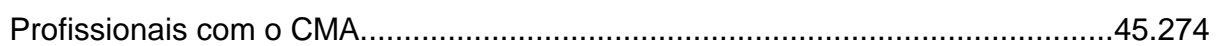

\subsection{O Mercado de Trabalho para o Recém-formado}

De maneira geral o mercado de trabalho nos Estados Unidos tem andado mal das pernas na ultima década, atingindo em 1.992 um nível. de desemprego igual a 7,1\%. Há quem chame esta situação de recessão nacional.

Uma pesquisa recente realizada pela Michigan State Universtty (18) mostra que mais de 500 grandes companhias projetam de $10 \%$ a $15 \%$ de redução de oferta de emprego para os graduados em 1991 , a despeito de o numero desses graduados ter aumentado em relação ao ano anterior. 
Todavia, se o mercado não está propicio nas grandes empresas, curiosamente muitas oportunidades tem sido abertas em pequenas e medidas empresas as quais começam a visitar as universidades locais em busca de talentos recém-formados.

De janeiro de 1990 a janeiro de 1991, conforme as estatísticas publicadas pela revista e Human Resourse Executive (27), os 50 maiores empregadores dos Estados Unidos tiveram um desempenho muito fraco, e deste universo 19 empresas mais demitiam que contrataram. Grandes empresas como Mirriot, Chysler. J. C. Penney, IBM, AT\&T e Kodak demitiram mais de 30.300 empregados.

Felizmente, dos 50 maiores empregadores, empresas como Wall-Mart Stores Inc., General .Motors, Ford, Pepsi Co. e outras, mais contrataram que demitiram, totalizando um saldo positivo de 28.000 novos empregos.

Todavia, este nível de contratação foi muito baixo. De acordo com o Bureau of Labor Statistics (27) , mais de $80 \%$ dos novos empregos foram gerados por empresas americanas com menos de 250 empregados.

\subsection{Salários Iniciais}

A seguir apresentamos um quadro (18) de acordo com o Salary Report 1990 -1991 produzido pela Michigam State University, que mostra os salários iniciais estimados para os bacharéis de 1991 que irão entrar no mercado de trabalho. O quadro mostra, ainda, o acréscimo da contratação previsto para 1991 em relação a 1990.

Como se pode observar, a Contabilidade esta em décimo lugar em termos de salários iniciais e em primeiro lugar na área de Business. A oferta de novos empregos nesta área deverá crescer $2,8 \%$ em relação ao ano anterior (o que não é um percentual animador). Observe que os salários iniciais são para bacharéis, mas para os pós-graduados há acréscimos relevantes.

\section{Especialização}

Engenharia Química

Engenharia Mecânica

Engenharia Elétrica

Ciência da Computação

Engenharia Industrial

Medicina

Engenharia Civil

Enfermagem

Química

Contabilidade

Administração Financeira

Administração de Negócios

Geologia

Marketing/Vendas

Matemática

Administração de Pessoal

Agricultura

\section{Salário Inicial}

$\begin{array}{ll}\text { U\$\$ } & 38.114 \\ \text { U\$\$ } & 34.715 \\ \text { U\$\$ } & 34.658 \\ \text { U\$\$ } & 33.238 \\ \text { U\$\$ } & 32.794 \\ \text { U\$\$ } & 30.504 \\ \text { U\$\$ } & 29.508 \\ \text { U\$\$ } & 29.449 \\ \text { U\$\$ } & 29.364 \\ \text { U\$\$ } & 27.866 \\ \text { U\$\$ } & 25.869 \\ \text { U\$\$ } & 24.992 \\ \text { U\$\$ } & 24.636 \\ \text { U\$\$ } & 24.273 \\ \text { U\$\$ } & 24.168 \\ \text { U\$\$ } & 23.863 \\ \text { U\$\$ } & 23.486\end{array}$

\section{$\%$ de aumento em} relação a 1990 
Comunicação

Ciências Sociais

Estudos Liberais

Admlnistração de Hotel/Reset.

Publicidade

Educação

Telecomunicações

Retailing

Ecologia Humana

Jornalismo

Recursos Naturais
U\$\$ 22392

U\$\$ 22.610

U\$\$ 21.655

U\$\$ 21.555

U\$\$ 21483

U\$\$ 21.063

U\$\$ 20.499

U\$\$ 20.360

U\$\$ 20.202

U\$\$ 19.516

U\$\$ $\quad 19.496$
$4,7 \%$

$6,1 \%$

$5,8 \%$

$3,9 \%$

$2,3 \%$

$2,0 \%$

$3,0 \%$

$5,0 \%$

$2,5 \%$

$2,1 \%$

$2,3 \%$

\section{Profissões do Inicio do Próximo Milênio}

Após uma recente pesquisas (34) de inovações globais em ciências e tecnologia, foram identificadas 20 novas áreas que poderão modelar as carreiras na década de 90 para aplicação no próximo milênio. Esta pesquisa demonstra que áreas como a Contabilidade, Publicidade, Bancos, Editoração, Bem-estar Social e Telecomunicações serão significativamente alteradas por estas vinte novas áreas. São elas iremos colocar os respectivos títulos em inglês para não corrermos o risco de cometer distorção.

01) Genetic Engineering

02) Advanced Biochemistry

03) Advanced Computers

04) Bioelectricity

05) Multi-sensory robotics

26) Artificial Intelligence

07) Parallel Processing

08) Digital Electronics

09) Lasers

10) Fiber Optics

11) Optical Data Storage

12) Microwaves

13) Advanced Satellites

14) Photovoltaic (PV)

15) Micro mechanics

16) Molecular Design

17) New Polymers

18) High-tech Ceramics

19) Fiber-reinforced Composites

20) Superconductors

\section{Currículo}

\subsection{Graduação}

Normalmente, nas Business School nos Estados Unidos, num curso de graduação são oferecidas as seguintes disciplinas contábeis: Contabilidade Introdutória, Contabilidade Intermediária, Contabilidade Tributária, Contabilidade de Custos, Contabilidade gerencial, Contabilidade Avançada, Contabilidade do Setor Publico e Sistemas Contábeis. 
Conforme levantamento realizado peio Prot Doyle Z.Williams (05) o numero de horas por semana no semestre varia de uma instituição para outra, na seguinte proporção:

Disciplina e horas por semana

Percentual de Instituição

\section{Contabilidade Introdutória}

3 horas

$50,8 \%$

4 - 5 horas

$14,4 \%$

6 horas

$23,2 \%$

7 ou mais

$11,6 \%$

Contabilidade Intermediaria

Ate 5 horas

6 horas

$65,2 \%$

7 horas ou mais

\section{Contabilidade Tributária}

3 horas ou menos

$58,3 \%$

4 horas

$11,0 \%$

5 horas

$3,1 \%$

6 ou mais

$27,6 \%$

\section{Contabilidade de Custo e Gerencial}

3 horas

$63,3 \%$

4 horas

$12,5 \%$

6 horas

outras

\section{Contabilidade Avançada}

3 horas
4 - 5 horas
6 horas
outras

\section{Auditoria}

3 horas

4 - 6 horas

outras

\subsection{Sugestão de carga Horária}


Em 1988, O Comitê Executivo para a Educação Contábil do AICPA aperfeiçoou a proposta de distribuição de carga horária para os cursos de Contabilidade, como segue (9) :

Educação Geral em torno de $46 \%$ da carga horária

(Ética, Comunicação, Ciência do Comportamento, Economia, Computação, Contabilidade Elementar, Matemática, Estatísticas, Psicologia, História, Línguas, Artes etc).

Administração e Negócios. em torno de $30 \%$ da carga horária

Economia - Sistema Monetário e Teoria, Aspectos Legal e Social dos Negócios, Legislação do Negócios, Marketing, Finanças, Organização e Comportamento, Aplicações quantitativas e Negócios, Contabilidade em Comunicação, Ética Administrativa etc.

Contabilidade. .em torno de $24 \%$ da carga horária Contabilidade Financeira Teoria e Aplicação de Problemas nas Contabilidades Intermediária e Avançada, Contabilidade de Custos e Gerencial, Impostos, Auditoria, Sistemas de informação. (Responsabilidade e Ética Profissional etc)

E interessante notar que nesta proposta se inclui Contabilidade Elementar ou Básica dentro de Educação Geral, pois e considerado um tópico comum para diversas áreas e não só ao curso de Contabilidade.

\subsection{Algumas Propostas de Currículo}

\subsubsection{Graduação}

Além de se receber um Guia Geral (timetable) distribuído pela universidade com, até, seis meses de antecedência do inicio das aulas (contendo horário, curso, disciplinas, nome dos professores,...) e comum a divisão de Contabilidade propiciar ao estudante de graduação um guia sugerindo um elenco de matérias cara obter o seu bacharelado e, em alguns casos, atingir os pré-requisitos para o exame CPA. A seguir, apresentamos um modelo deste guia para um curso de 4 anos. Como no estado onde a universidade esta localizada será exigido (28) cara o exame CPA 5 anos de curso, o aluno devera, pelo menos, iniciar o mestrado para atender o numero mínimo de credites exigidos:

\section{CULTURA GERAL}

Inglês - 3 cursos:

Inglês - Composição (redação)

Inglês - Redação e Literatura

Optativa em inglês

\section{HUMANAS - 3 cursos}

Optativa 1

Optativa 2

Optativa 3

\section{MATEMÁTICA - 2 cursos}

Álgebra 
Calculo

\section{CIENCIA DA COMPUTACAO - 1. curso}

Ciência do Computador

CIÉNCIA SOCIAL - 3 cursos

Psicologia Geral

Psicologia Social

Optativa

\section{CIÊNCIAS NATURAIS E MATEMATICA - 2 cursos}

Optativa 1

Optativa 2

\section{ÁREAS AFINS}

Introdução a Análise Econômica

Macroeconomia

Macroeconomia

Estatística 1

Estatística 2

Legislação de Negócios

Marketing

Métodos Quantitativos

Finanças

Aspectos Comportamentais em Organização

Administração Geral

Optativas (5 optativas)

\section{ÁREA CONTÁBIL}

Contabilidade Introdutória

Contabilidade de Custos

Contabilidade Intermediária (2 semestres)

Sistemas Contábeis

Contabilidade Gerencial

Contabilidade de Impostos

Auditoria e Sistema

Contabilidade Avançada

\section{MESTRADO}

Para atender as exigências estaduais na obtenção do CPA, há necessidade de cursar mais oito disciplinas, completando cinco anos. Na área Contábil as disciplinas oferecidas são: 
Teoria Contábil Normativa Contabilidade Gerencial Avançada Teoria Contábil Aplicada

Auditoria Avançada

Teoria e Pratica da Contabilidade Financeira

Analise e Controle de Custo

Sistemas e Teoria de Auditoria

Teoria e Pratica dos Impostos

\subsubsection{MBA - Master of Business Administration}

Há inúmeros "MBA" nos SUA. A maioria deles e de dois anos em penedo integral, podendo o estudante optar sua concentração para Contabilidade, Finanças, Recursos Humanos, Administração Hospitalar, Negócios Internacionais, Administração, Mercadologia etc.

Apresentamos um currículo aproximado, sugerido pela maioria das instituições e em seguida as opções para a concentração em Contabilidade:

1 ANO

\section{$1^{\circ}$ Semestre}

Conceitos Contábeis

Fundamentos Econômicos para Negócios

Administração e Organização

Estatística Administrativa

Comunicação Administrativa

Computação Administrativa
2 ANO

\section{Semestre}

Negócios, Lei e Sociedade

Sistemas de Informação Gerencial

Política Estratégica e Planejamento

Optativa na área de concentração

Optativa na área de concentração

\section{Semestre}

Controle e Análise de Custo

Administração Financeira

Economia Administrativa

Marketing

Operações Gerais
Comportamento organizacional e Gerencial

Optativa na arma de concentração

Optativa na arma de concentração

Optativa Geral

\section{Optativas na área Contábil}

Contabilidade Financeira

Imposto de Renda e Decisões Administrativas

Problemas Contemporâneos da Contabilidade Financeira 
Problemas Contemporâneos da Contabilidade Gerencial

Auditorla Avançada

Pesquisas sobre Impostos Federais

Tópicos Especiais em contabilidade

E importante que se diga que embora os MBA sejam extremamente populares nos Estados Unidos, eles também se encontram em reformulação, pois, de certa forma há insatisfação com o conteúdo e com a pedagogia aplicados, como revela uma recente pesquisa '50) realizada pelas universidades de Wharton, Chicago e Columbia.

\subsubsection{Doutorado}

Os programas de doutor meY1to em uma Business School envolvem disciplinas bastante diversificadas, variando de uma Instituição para outra. A titulo de exemplo apresentamos um programa (30) de uma universidade bem conceituada nos EUA.

\section{Disciplinas Básicas:}

- Princípios de Desenvolvimento Societário e o Futuro

- Desenvolvimento Humano

- Sistemas Social e Organizacional

\section{Especializacões Avançadas:}

- Teoria e Comportamento Organizacional

- Abordagens Modernas para a Compreensão e Administração de Organizações

- Estudos de Casos Avançados/Administração e Gerêncla

Dissertação: Pesquisa inédita

Em doutorados com ênfase maior em contabilidade, as disciplinas mais oferecidas na área contábil são: Seminários de Contabilidade Contemporânea; Workshop em Contabilidade; Seminários em Contabilldade gerencial; Pesquisas em Impostos; Teoria Contábil Normativa; Tópicos sobre Métodos Quantitativos Aplicados a Contabilidade Gerencial Avançada; Teoria Contábil Aplicada; Auditoria Avançada. Problemas de Contabilidade Avançada; etc.

Mais dados sobre o Mestrado/Doutorado são tratados no segmento "Alguns Dados quantitativos sobre a Contabilidade" e em outros segmentos neste trabalho.

\section{$7 \quad$ Sala de Aula}

\subsection{Turma Grande x Turma Pequena}

Basicamente são encontrados bis tipos de classes no ensino da contabilidade nos EUA: turmas pequenas ate 40 alunos, e turmas grandes, atingindo ate 300 alunos ou mais em situações especiais.

As turmas grandes são comuns em inicio de curso, em matérias obrigatórias como Contabilidade Introdutória, Introdução a Psicologia, Sociologia etc.

No caso de Contabilidade Introdutória (Contabilidade Financeira), cabe ao professor fazer uma exposição sobre o assunto programado, utilizando-Se dos melhores recursos Audi-visuais, sem, entretanto, propiciar calorosos debates. Esta turma grande e dividida em pequenos grupos (não mais de 30) para uma 
vez por semana, sob a responsabilidade de um Assistente por grupo, reunir-se em salas separadas, para debater e tirar duvidas do conteúdo apresentado pelo professor Na matéria. Esta forma de ensino e comum em muitas universidades.

De maneira geral, as outras disciplinas na área contábil são ministradas em turmas pequenas, algumas vezes em sessões e em períodos diferentes, propiciando ao estudante um melhor ajustamento do seu horário. Assim, Contabilidade Intermediária, de Custo, Gerencial etc. são oferecidas, por exemplo, de manhã e a tarde, permitindo ao estudante a melhor opção. Esta opção, ainda que definitiva, não impede ao interessado alterar seu horário em termos excepcionais ou, ate mesmo, assistir novamente, na sessão seguinte, um assunto onde pairaram duvidas.

\subsection{Características das Salas de Aula}

Embora seja difícil generalizar este item, pois há muitas peculiaridades, podemos dizer que normalmente as aulas para turmas grandes são desenvolvidas em auditórios especiais para esta finalidade.

As aulas para turmas pequenas são, normalmente, desenvolvidas em classes cujo formato é no estilo de anfiteatro e a disposição das carteiras é em forma de diversos "U", de maneira que os alunos tem a visão de grande parte dos seus colegas, facilitando muito os debates.

No primeiro dia de aula é comum cada aluno escolher um lugar, devendo manter-se nele até o final do curso. O professor geralmente passa um mapa contendo o lay out das carteiras para ser assinalado pelos alunos identificando o lugar escolhido. A troca de lugar é possível após uma consulta prévia ao professor.

Esse sistema permite ao professor (que permanece no meio do primeiro "U" de carteiras) no nível mais baixo do anfiteatro memorizar o nome dos alunos e o local fixo onde ele fica assentado. comum, portanto, o aluno ser chamado pelo nome já que o professor tem condições de avaliar a sua participação nas aulas, sua freqüência e pontualidade.

Além dos recursos audiovisuais comuns em sala de aula, o professor conta com um conjunto de três lousas que estão sobrepostas, sendo facilmente manipuladas em duas alturas atrás de trilhos. Assim o instrutor faz anotações na lousa de baixo, que esta no nível normal e quando the convier suspende a mesma para um nível superior, iniciando as anotações na lousa que esta em segundo ligar. Tanto a segunda como as terceiras lousas são manipuláveis para cima e para baixo sem a menor dificuldade.

Isto permite, e é muito interessante, principalmente para o ensino da Contabilidade, um arquivo de anotações de praticamente toda a aula, podendo-se retornar ou avançar nestas anotações com muita facilidade, a qualquer momento.

\section{Avaliação Presença}

\subsection{Avaliação}


Além das provas tradicionais, é comum os professores aplicarem rápidos testes (quis) a cada duas ou três semanas. Normalmente, estes testes abrangem a matéria das ultimas aulas, tomando não mais que 20 minutos no inicio da aula. Alguns professores programam o tempo, porem outros o aplicam sem prévio aviso.

Todas as avaliações são devolvidas aos estudantes, corrigidas, com nota, normalmente na aula seguinte. E comum também o professor comentar questão por questão, permitindo ao estudante o debate sobre a solução proposta. Esta metodologia faz parte do processo de aprendiz agem.

Independentemente do desempenho do aluno, normalmente na um exame em cada disciplina, no final do semestre. As aulas são interrompidas em media uma ou duas semanas antes dos exames, permitindo ao estudante um tempo de concentração para demonstrar seu aprendizado na disciplina.

$\mathrm{Na}$ avaliação final, entram diversas variáveis como participação em aula e entrega dos exercícios. Um exemplo de critério de avaliação, por exemplo, é:

\begin{tabular}{|c|c|}
\hline Provas (duas no semestre).............. &. $.30 \%$ \\
\hline Quizzes (quatro ou mais no semestre). & $\ldots 20 \%$ \\
\hline Exercícios entregues.. & $\ldots 10 \%$ \\
\hline Participação na aula... &. $.10 \%$ \\
\hline fin & 30 \\
\hline
\end{tabular}

Geralmente, os professores distribuem no primeiro dia de aula, junto com a proposta do curso, parte da definição de mau procedimento acadêmico contida no regulamento universitário. Por exemplo: "o mau procedimento acadêmico pelo estudante abrangera, mas não estará limitado nisto, atitudes indesejáveis que interrompem o bom andamento da aula; dar ou receber ajudas não autorizadas nas avaliações (exames provas..), ou nas anotações em aula, nos trabalhos, ou nos relatórios, ou em outras tarefas; tendo conhecimento, representar erroneamente ou de forma distorcida as fontes de qualquer trabalho acadêmico

...." A descrição de mau comportamento acadêmico esta contida detalhadamente no Guia Geral (timetable) distribuído meses antes do inicio das aulas, nos tópicos Direitos e Responsabilidades do estudante.

\section{2 Ética do Estudante}

Apesar da rigidez no estabelecimento do procedimento do estudante visto no parágrafo anterior, a ética do estudante e um assunto muito discutido atualmente nos Estados Unidos. Uma pesquisa sobre a atitude ética dos estudantes realizada por Josephson Instituto of Ethics (33) em Los Angeles mostra que 75\% de todos os estudantes de graduação dizem já terem trapaceado ao menos uma vez no último ano.

Em recente pesquisa abrangendo 300.000 estudantes de graduação realizada pela Higher Education Researche Institute da Universidade da Califórnia - Los Angeles (33), 37\% admitem trapacear em testes (exames, provas) enquanto que $57 \%$ disseram já ter copiado as tarefas de casa valendo nota que são entregues ao professor.

O pesquisador Miichael Josefhson da empresa acima referida, bastante preocupado com a ética acadêmica, principalmente em virtude da competição de boas notas para melhorar o currículo, afirma:" se há estudantes que. trapaceiam na escola por que não trapaceariam também no seu local de trabalho?"

De certa forma, após a existência de alguns escândalos rio mundo dos negócios desse país e algumas atitudes discutíveis de empresários famosos, há empresas americanas preocupadas com o grau de honestidade do candidato a ser contratado. No artigo chamado Ética publicado pela Managinq Your Carreer 
(33), o diretor de recursos humanos em Boston da Arthur Andersen \& Co (uma das "Big Six" empresas de Contabilidade nos EUA) David Clarkson, diz que há um novo grau de conscientização entre 05 empregadores sobre a ética dos estudantes e que estes (estudantes) não estão conscientes do comportamento adequado nesta Área. Segundo ele, isto traz preocupações para empresas como a dele a qual atualmente tem dado muita ênfase no sentido de avaliar o comportamento ético dos candidatos a servirem a empresa.

\subsection{Presença}

No que tange a presença, normalmente não há controle freqüência do aluno através de chamada, lista de presença, diário etc.

Como já abordamos, a entrega dos exercícios ou estudo de caso normalmente conta ponto para a nota do bimestre. Também, como já foi dito, as vezes são aplicados os testes rápidos (quiz) no inicio da aula sem prévio anuncio. Estes unannounced quizzes normalmente tem um peso maior que os testes programados. Em alguns casos eles têm o mesmo peso que as provas bimensais. Como a participação nas discussões durante as aulas e os estudos de caso também compõem a avaliação final, tudo isso, de certa forma, acaba induzindo o aluno a par na aula.

E possível observar um aviso no inicio do semestre nas propostas de cursos apresentadas pelos professores:

"Os professores são constantemente solicitados para apreciar o desempenho do estudante com o propósito de emprego. Uma fraca presença ou freqüentes atrasos no inicio das aulas ou ainda abandonar as aulas antes do seu término, será visto como falta de interesse na profissão contábil. Informações fornecidas em sala de aula não serão repetidas privativamente na sala do professor ou em qualquer outro lugar. Todas as avaliações e exercidos feitos em casa serão devolvidos individualmente somente em sala de aula".

O que se nota e a utilização de diversos instrumentos que motivam os alunos a estarem presentes nas aulas, sem a utilização da "chamada diária" propriamente dita

\section{O Professor}

\subsection{Informações Gerais}

quando se fala sobre professores, algumas questões sempre levantadas: Como é a carreira? Qual e o seu salário? Qual é a carga horária? Como são relacionadas estas características com docentes de outras áreas? As características estão mudando? Quantos professores trabalham em período integral?

De todas as respostas para estas perguntas, as que mais nos satisfizeram foram às apresentadas pelo American Institute of Certified Public Accountants cuja pesquisa mais recente (06) refere-se ao final da década de oitenta, portanto, bem atual para os nossos propósitos. As considerações a seguir são baseadas nesta pesquisa.

Nos Estados Unidos, basicamente, encontramos nas universidades Instrutor (lecturer), o Professor Assistente, o Professor Associado e o Professor Pleno (que equivale ao nosso professor titular). Na área contábil, 24,4\% já atingiram o ápice da carreira; 25,6\% são professores associados; 30,9\% são professores assistentes; $16,8 \%$ da carreira como instrutores juros e 2,3\% têm outras classificações. Comparados com outras áreas, estes dados não são os melhores possíveis,já que, em média, 29,2\% dos docentes 
americanos estão na categoria mais alta de professor pleno e $28,1 \%$ estão na qualidade de professores associados.

Atualmente, $80 \%$ dos docentes de Contabilidade trabalham em período integral nas universidades americanas. $61 \%$ dos docentes da pós-graduação e graduação são doutores. Ressalte-se que grande parte dos docentes não doutores estão em fase de conclusão do seu doutorado. $74 \%$ dos docentes em período integral possuem o certificado do CPA. Quando somado ao CMA, 85\%, no conjunto, possuem certificados profissionais, ou seja, foram submetidos a um difícil exame de qualificação profissional.

No que tange a área de especialização, 27\% concentraram-se em Contabilidade Financeira (Contabilidades Introdutória, Intermediaria e Avançada); 21,2\% em Custos e Contabilidade Gerencial; 14,9\% em Impostos; 11,2\% em Auditoria; 8,7\% em Sistemas de Informações; 2,7 em Empresas sem Fins Lucrativos e 4,0\% em outras áreas.

No que se refere à remuneração do docente período integral, por oito meses de aula, sem considerar os benefícios indiretos e a suplementação salarial (curso de verão - em junho e julho que corresponde a um semestre letivo, remuneração por pesquisa realizada, cursos especiais na própria universidade, consultoria, etc), a media salarial era bastante atraente no final da década de 80:

Nível $\quad \underline{\text { Doutor em Contabilidade } \quad \text { Média outros Cursos }}$

$\begin{array}{lrr}\text { Professor Pleno } & 61.000 & 47.400 \\ \text { P. Associado } & 51.000 & 35.300 \\ \text { P. Assistente } & 46.600 & 29.200\end{array}$
outras áreas.

Repare que a média da remuneração do Professor Associado esta mais de $50 \%$ acima que as

Normalmente um professor que pesquisa e dá aula no verão sabe que sua remuneração pode chegar próxima de cem mil dólares por ano. Ainda assim, o Professor não prejudicaria suas férias, pois teria livre agosto, parte de maio, partes de janeiro, semana da primavera etc. São ainda comuns os intercâmbios com outros paises, onde os docentes viajam constantemente sem despesas, valendo pontos para sua carreira.

Atualmente há universidades pagando até $\$ 60.000$ dólares para ingressantes na carreira. A razão básica é que são formados em media 160 novos doutores em Contabilidade por ano, sendo que demanda e, em media, de 700 doutores.

Em pesquisas mais recentes observa-se que a remuneração do docente contábil (Business) tem aumentado razoavelmente, ainda que na média, não seja a mais alta nas universidades em geral. Estes dados abaixo são revelados pelo Departamento Profiles, (School and University summaries 16) que mostra uma interessante comparação entre a Universidade de Kansas(A); um grupo de seis universidades(B) incluindo Cobrado, lowa, North Carolina, Oklahoma, Oregon e Kansas; a Associação Americana de Universidades $(C)$ - incluindo 14 universidades publicas (AAC-14); e o grupo das oito maiores universidades nos EUA (D)

- Chamada "Big Eight", como segue:
Escola
A
B
C
$\mathrm{D}$

Caderno de Estudos n07, São Paulo, FIPECAFI - Outubro/1992 


$\begin{array}{lllll}\text { "Business" } & \$ 68.000 & 65.318 & 71.747 & 61.570 \\ \text { Direito } & \$ 67.542 & 73.328 & 79.407 & 72.782 \\ \text { Engenharia } & \$ 57.098 & 65.828 & 70.426 & 63.749 \\ \text { Farmácia } & \$ 56.445 & 68.416 & 65.276 & 52.059 \\ \text { Arquitetura } & \$ 51.873 & 49.549 & 56.661 & 47.612 \\ \text { Artes Liberais } & \$ 50.393 & 54.522 & 57.448 & 51.540 \\ \text { Bem-estar Social } & \$ 48.811 & 57.115 & 54.635 & 46.218 \\ \text { Jornalismo } & \$ 44.003 & 53.475 & 52.463 & 48.568 \\ \text { Educação } & \$ 43.906 & 51.978 & 53.216 & 48.167 \\ \text { Belas Artes } & \$ 43.259 & 44.762 & 49.014 & 43.395\end{array}$

Estes salários são de professores plenos, em período integral, para mais ou menos oito meses de aula, não estando incluídos outras remunerações, beneficies indiretos e suplementações salariais.

Em relação à carga horária, ela esta caindo de ano para ano. 90\% dos docentes de Contabilidade ensinam 12 ou menos horas por semana e mais da metade dos docentes ensinam menos de dez horas por semana.

\subsection{Professores Catalogados}

Em 1991, a Prentice Hall (35) lançou a 17 edição do Guia dos Professores de Contabilidade, onde estão relacionados perto de 8.000 professores de Contabilidade das 700 escolas americanas cujos diretores responderam em tempo hábil as informações solicitadas.

Além dos professores e instituições de ensinos americanos, estão relacionados em torno de mil docentes de algumas instituições estrangeiras que responderam a pesquisa(35)

Cada professor está catalogado por ordem alfabética e por universidade, abrangendo os seguintes dados: Titulo obtido (ano e local), ranking do professor na instituição de ensino pience, associado,...) , telefone e endereço da instituição (bitnet, fax,...), ano que iniciou na instituição de ensino, disciplina que leciona, de que associação e membro e outros dados como CPA, CMA etc.

\section{Estudos Sobre a Qualidade de Ensino da Contabilidade}

\subsection{Trabalhos Sobre o Assunto}

Provavelmente, a maioria dos estudos relacionados com o ensino da Contabilidade nos Estados Unidos, nos últimos anos, tem tratado de problemas relativos á qualidade do ensino.

Segundo o Prot. Doyle Z. Williams da Universidade do Sudeste da Califórnia (05), três, entre os muitos trabalhos sobre a qualidade da educação contábil, têm recebido as maiores atenções e provavelmente mais ampla aceitação. São eles:

- Os estudos de Gordon e Howel (02)

- Os estudos de Pierson (03) ; e

- "Horizontes Para Uma Profissão", de Roy and MacNeill (04). 
Tanto o trabalho de Gordon e Howell, como o de Pierson foram publicados em 1959. Embora a ênfase desses estudos tenha sido para o ensino de Administração e Negócios, encontram-se relevantes considerações no que tange ao ensino da Contabilidade.

Ainda que o impacto desses estudos continue afetando o estágio atual do ensino da Contabilidade, algumas mudanças estimuladas por estes relatórios são palpáveis. Por exemplo, durante a década de sessenta, o ensino da Contabilidade, como em geral na área de Administração e Negócios, tem se tornado progressivamente integrado com outras disciplinas. Num nível introdutório, maior atenção foi dada para uma orientação prática e dados contábeis para a finalidade de tomada de decisão passaram a ter um papel proeminente. Por fim, num nível mais avançado, técnicas quantitativas foram introduzidas, recebendo grande ênfase no presente.

O trabalho Horizonte Para uma Profissão, de Roy e MacNeill (04) focalizou especificamente as necessidades do ensino para formar um CPA (Contador Publico). Este trabalho propõe um corpo comum de conhecimentos necessários para o profissional se iniciar como um CIÃ. O trabalho encontrou uma aceitação geral nos Estados Unidos, causando impacto sobre o colegiado de educação contábil no que tango a aumento na ênfase sobre a aprendizagem conceitual; trouxe atenção adicional para/e encorajando a aplicação de instrumentos como os computadores métodos quantitativos; e pressagiou ensino formal para a pós-graduação em Contabilidade.

Digno de menção aqui é o relatório de um estudo realizado por um comitê indicado pela associação dos Contadores Americanos (AAA) em 1986 (08) considerando a futura estrutura, o conteúdo e o campo de ação do ensino da Contabilidade. Este comitê fez 28 considerações e mostrou que o ensino contábil universitário deveria ser reestruturado para melhor atender aos anseios da profissão. A conclusão deste comitê, ao realizar uma revisão sobre a eficiência dos programas de Contabilidade, é que enquanto a profissão tem mudado nos últimos anos, o ensino da contabilidade permaneceu Inalterado, requerendo uma reorientação até o ano 2000.

\subsection{Contribuições das Empresas de Auditoria}

Com o artigo "Perspectivas no Ensino: Captação para o Sucesso na Profissão Contábil", (07) as maiores empresas de auditoria nos Estados Unidos se reuniram para apresentar propostas a seres desenvolvidas no ensino da Contabilidade com o objetivo de aperfeiçoar a qualidade do profissional contábil, especialmente o Contador Publico.

Este documento diz que a responsabilidade de desenvolver o currículo e a adequação da metodologia de ensino, num primeiro plano, pertencem a comunidade acadêmica. Todavia, estas empresas entendem que qualquer esforço bem sucedido para aperfeiçoamento do ensino da Contabilidade só será através da união entre a comunidade acadêmica e a comunidade profissional.

Como parte desse esforço coordenado, as empresas de auditoria (Arthur Andersen \& Co., Arthur Young, Coopers \& Lybrand, Deloitte Haskins \& Sells., Ernst \& Whinney, Peat Marwick Main \& Co., Pric.

Waterhouse e Touche. Ross) estão doando num período de cinco anos uma quantia acima de quatro milhões de dólares as universidades para darem apoio ao desenvolvimento de um currículo que responda mais objetivamente as necessidades da profissão.

Estas empresas afirmam a necessidade de reexaminar o processo educacional da Contabilidade em virtude de o mundo dos negócios ser hoje muito mais dinâmico e completo que pouco tempo atrás. Tecnologias avançadas, proliferação de regulamentos, globalização do comercio e transações complexas, 
fazem do dia-a-dia do profissional contábil um grande desafio. Tudo isso requer deste profissional ampla área de conhecimento e habilidade para servir a comunidade empresarial.

\subsubsection{Sugestões Objetivas}

O documento em analise propõe que a educação para os futuros contadores deveria produzir profissionais que tivessem amplo Conjunto de habilidade e reconhecimento. Estas habilidades (competência) são divididas em três categorias:

\section{a) Habilidade em Comunicação}

A atividade contábil exige que seus profissionais sejam capazes de transferir e receber informações com facilidade.

Os profissionais contábeis deverão ser capazes de apresentar e defender suas posições através de exposições formais ou informais.

Verbais ou escritas. Deverão ser capazes de se comunicarem no nível que os homens de negócios. À velocidade e a adequação da informação contábil deverão acompanhar o ritmo das crescentes mudanças no mundo dos negócios.

\section{b) Habilidade Intelectual}

Quando consultado, o profissional contábil. devera ser capaz de usar sua criatividade para estruturar e apresentar rápidas soluções dos problemas que muitas vezes não lhe são familiares. Deverá ser capaz de identificar e, se possível, antecipar os problemas, propondo soluções viáveis. O profissional contábil enfrenta constantes desafios e pressões. Conflitos de demanda, solicitações imprevisíveis e coincidências de prazo limite para o término de serviços são exemplos de situações que ele terá de administrar. Isto requer habilidade e critério para selecionar e assumir prioridades dentro das limitações de tempo e recursos.

\section{c) Habilidade nos Relacionamentos com as Pessoas}

A habilidade em trabalhar com outras pessoas e em grupo para executar determinadas tarefas e essencial. O profissional contábil deverá ser capaz de influenciar outros; de organizar e delegar trabalhos; de motivar e desenvolver outras pessoas; e de resolver e suportar conflitos.

Quanto aos conhecimentos indispensáveis ao profissional contábil, estas empresas de auditoria também se dividem em três categorias:

\section{a) Conhecimentos Gerais}

Conhecimento do fluxo dos acontecimentos dentro da história e das diferentes culturas do mundo atual; habilidade para interagir com diversos grupos de pessoas de diversos níveis culturais para intercâmbio; ter sensibilidade e capacidade de visualizar os contrastes em relação as forças econômicas, políticas e sociais no mundo; ter experiência na abordagem de juízos de valores.

\section{b) Conhecimento em Organização e negócios}


o profissional contábil deveria ter conhecimento das forças econômica, social, cultural e psicológica que afetam a organização onde ele presta serviços; deveria entender também o fluxo interno operacional das organizações e ser capaz de aplicar seus conhecimentos em situações especificas; deveria ser capaz de absorver as rápidas mudanças no mundo dos negócios e na tecnologia e aplicar na organização onde presta serviços.

\section{c) Conhecimento Contábil e de Auditoria}

Um profundo conhecimento da Contabilidade abrange desde a historia do pensamento e da profissão contábil, tanto como o conteúdo, preparação, conceito, estrutura e significado dos relatórios contábeis, sejam eles de finalidade interna ou externa; métodos para coletar, reunir, sumarizar e analisar os dados financeiros. O profissional contábil deveria ser capaz de usar os dados financeiros, exercer julgamento, avaliar riscos e resolver os problemas efetivos. Enfim, um desenvolvimento do raciocínio conceitual e analítico relativo á Contabilidade.

Ë lógico que para obter todos este requisitos não bastam apenas bons cursos universitários. A profissão e o próprio ensino deverão ser atraentes a ponto de alcançarem os jovens talentos. A educação continuada vem ainda completar este ciclo de desenvolvimento da capacidade profissional.

\subsubsection{Os Desafios da Educação Contábil}

O documento em analise aborda ainda que apenas fundamentais mudanças nos atuais currículos não são suficientes para atingir um estágio ideal. $O$ estilo de ensino atual baseado nos livros textos, no ensino intensivo de certas regras e nas preleções não deveria sobreviver como fonte primaria do ensino da contabilidade. Novos métodos deveriam ser explorados. Um envolvimento maior por parte do estudante nas atividades de ensino/aprendizagem e reivindicado, como, por exemplo, em seminários, simulações, trabalhos escritos (pesquisas), análise de casos,...sempre de posse da tecnologia mais avançada.

À atividade em equipe com tarefas que mais tarde irão enfrentar na profissão, propiciando soluções em conjunto, numa moderna dinâmica, também é reivindicado.

No que tange aos professores constata-se que a maioria das informações (e até conhecimento) dos docentes é obtida através de fontes secundárias, normalmente livros textos e pronunciamentos, não havendo um constante acesso ao meio ambiente da Contabilidade (ou na realidade contábil). Ao contrário das outras profissões, como por exemplo na área de saúde, onde o docente simultaneamente desenvolve a profissão e ensina, o docente contábil tem um restrito acesso a pratica profissional.

Em diversas profissões os seus conteúdos estão disponíveis para estudo e análise, como é o caso, por exemplo, de Direito. A confidencialidade de boa parte da Contabilidade impede ao docente desta área ter acesso às informações necessárias sobre a evolução da atividade profissional (estando desprovido de um "laboratório", de uma "clinica" profissional). Esta ausência de informação, este distanciamento entre o conteúdo pedagógico e a realidade pratica em constante mudança, de certa forma prejudica o docente que irá moldar a mente do futuro profissional.

Ainda que não haja um modelo proposto para aperfeiçoar a interação entre os academicistas e a prática contábil, há um estorço para que isto aconteça através de semanários, intercambio com empresas e conferências conjuntas.

\section{Algumas Propostas de Mudanças nos Programas de Contabilidade}


$\mathrm{Na}$ verdade, boa parte das universidades americanas esta respondendo aos anseios da própria profissão no sentido de promover profundas mudanças na educação contábil no pais.

Para tanto foi criada a AECC (Accounting Educational Change Comission) visando basicamente mudanças na preparação acadêmica dos futuros profissionais contábeis.

Universidades que não compõem a AECC têm submetido suas propostas esta comissão no sentido de haver maior interação nas mudanças. No momento, a frente, Currículo Contábil, a Computação e o Ensino da Contabilidade, fazemos referências as instituições que se filiaram a AECC e algumas que estão submetendo a sua proposta para esta comissão.

universidades.

A seguir descrevemos algumas propostas de mudança, considerando algumas dessas

\subsection{Universidade Estadual do Arizona}

A Universidade Estadual do Arizona publicou uma proposta, como resultado de sucessivas reuniões, de mudança no seu curso e currículo, têm servido como guia para algumas universidades igualmente preocupadas em mudar. As mudanças consideradas fundamentais nesta proposta são:

\section{- $\quad$ Reestruturação da Contabilidade Introdutória}

Um primeiro aspecto e dirigir o ensino da Contabilidade para aqueles que irão se profissionalizar em Contabilidade, diferenciando dos outros estudantes que cursam contabilidade mas que não serão profissionais na área. Dessa forma, as sessões de laboratório serão publicadas apenas aos estudantes que optam por Contabilidade como principal área de interesse.

O curso de Contabilidade Introdutória será dado em dois semestres: o primeiro dentro da perspectiva do usuário da Contabilidade (o múltiplo uso da informação contábil) o segundo, centro de uma metodologia passo-a-passo (conforme o desempenho de cada estudante), será a nível de laboratório, voltado especificamente para os futuros contadores (enfatizando-se os procedimentos contábeis com o uso do computador] . Dessa forma, o estudante com interesse principal em Contabilidade estará malis bem preparado para outras matérias subseqüentes.

\section{- Sistemas de Informação Contábil}

Esta será a primeira disclpllna, pela seqüência, para o estudante que optou em se profissionalizar em Contabilidade, após ter cursado os dois semestres de Contabilldade Introdutória. Este curso utilizará ampla abordagem de Sistemas de informação Gerencial, ao contrario de uma restrita perspectiva de um sistema de informação Contábil. Neste curso serão identificados e discutidos os vários usuários da informação contábil e o sistema de informação relacionado com cada relatório contábil. Neste contexto tem-te uma visão dos Relatórios internos, externos, dos tributos e da auditoria como subsistemas de um sistema de informação global.

(Este curso será pré-requisito para os mais adiantados na área contábil e provera conhecimentos de sistemas da informação e habilidades necessários para os outros cursos ha mais cinco cursos na seqüência).

\section{- $\quad$ Laboratório Contábil}

Dentro desta proposta haverá três horas por semana no laboratório e três horas em sala de aula. As Ciências Físicas têm usado esta abordagem nos Estados Unidos com muito sucesso por varias décadas e a pratica (experiência) em laboratório é um componente integrante nesta área. O laboratório transmite uma 
experiência para os estudantes para reforçar os conceitos apresentados em sala de aula. Dentro desta perspectiva, o laboratório deverá ser usado para todas as disclplinas contábeis (exceto Contabilidade Introdutória 1).

Para aumentar o tempo disponível para a discussão de Casos, algumas atividades típicas de sala de aula serão transferidas para o laboratório. Por exemplo, no que tange á maior parte da matéria pratica (mecânica e procedimentos contábeis), com base no computador. será exclusiva de laboratório. Os testes, exames e outras avaliações serão realizados no laboratório, proporcionando mais tempo disponível para a interação professor/estudante e estudante/estudante na sala de aula. Simulações computadorizadas, aplicativos no computador e experimentos comportamentais serão componentes importantes da atividade de laboratório. Será usado videoteipe para a apresentação de novos materiais e prover informações básicas importantes para facilitar a discussão da sala de aula. Por exemplo, existem excelentes "vídeos" disponíveis sobre éticas de negócios e diversos outros assuntos, para, em seguida, ser discutido em sala de aula.

\section{- $\quad$ Método de Caso}

Muitos mestrados em Administração e Negócios e alguns cursos :e Contabilidade usam o método de Casos com muito sucesso. Este método força o estudante a se envolver mais no processo de aprendizagem. além de serem exibidos para os estudantes os problemas reais a serem enfrentados, muitos dos quais estão relativamente sem estruturação (ou uma boa solução). Os estudantes aprendem a aplicar teoria e conceitos para os problemas que não são solucionados que não são solucionados nos livros textos. Com base na instrução do método de Caso, os estudantes tornam-se participantes ativos no processo de aprendizagem. o qual devera aumentar a aprendizagem obtida. O método de Caso encoraja o estudante a aprender de forma descontraída, distanciando-se dos processos de memorização de regras, definições e procedimentos.

\section{- Seqüência de Disciplinas}

A seqüência proposta de disciplinas é: 1) Contabilidade Introdutória I; 2) Contabilidade Introdutória II: 3) Sistemas de Informação Contábil; 4) Relatórios Externos I; 5) Contabilidade

Tributaria; 6) Relatórios Externos II; 7) Relatórios Internos; e 8) Auditoria.

Cada curso fará uso do laboratório e estudo de Caso. Os estudantes deverão completar o curso de Sistemas de Informação contábil para se inscrever em Relatórios Externos e outras disciplinas. Cada curso será estruturado sobre os reconhecimentos contábeis e habilidade adquiridos no curso anterior. Por exemplo, o estudante terá Impostos antes de Relatórios Externos II e Relatórios Internos. Os professores dessas duas disciplinas utilizarão forma apropriada as implicações tributárias nos tópicos a serem discutidos.

\section{- Diretrizes para Reestruturação do Curso de Contabilidade}

- O critério dominante será que o estudante deve ser um participante ativo no processo de aprendizagem.

- Os objetivos do ensino serão estabelecidos antes do desenvolvimento de cada curso. A ênfase estará na definição do que os estudantes deverão conhecer ou ser capazes de fazer ao terminar cada curso.

- Ë possível [e não desejável] cobrir todos 05 tópicos contábeis num curso normal de Contabilidade. Cabe ao corpo docente selecionar os pontos a serem tratados. Para isso haverá como subsídios levantamentos e análise das necessidades, realizados pelo próprio departamento.

- O Laboratório contábil será utilizado para todas as disciplinas de Contabilidade. Caso será integrado no curso de Contabilidade, havendo .seqüência natural em cada disciplina. 
- Também os trabalhos escritos e as apresentações (seminários) serão integrados na seqüência normal das disciplinas contábeis.

- O estudo de ética e comportamento ético serão incorporados dentro de cada disciplina contábil.

Apresentação OH grupo, debates e simulações serão incluídos "ao seu tempo" nos cursos da área contábil. Profissionais contábeis convidados participarão em cada disciplina contábil, apresentando, desenvolvendo e/ou avaliando tópicos relevantes.

- Atividades de ensino que não requerem a presença do professor serão desenvolvidas no laboratório.

- Os estudantes utilizarão em proporção maior a instrução com base computador em comparação com outros instrumentos.

- As avaliações serão realizadas no laboratório.

\subsection{Universidade de Illinois e Universidade de Notre Dame}

Conforme entendimento dessas universidades, enquanto as exigências para um profissional contábil. eficiente tem mudado substancialmente durante os últimos 25 anos, o ensino da Contabilidade tem se mantido quase inalterado. Assim, ampla reformulação se faz necessária, tanto no curso como na pedagogia do ensino da Contabilidade.

O departamento de Contabilidade da Universidade de Illinois em Ubana/Champainq, considerado o numero um (veja item 20 deste trabalho) no ensino da Contabilidade nos EUA, acabou de lançar o projeto "Discovery', em conjunto com a Universidade de Notre Dame. Este projeto visa ao desenvolvimento de um protótipo de um currículo inovador para ser implementado em larga escala nas universidades americanas".

O primeiro estagio deste projeto terá a duração de cinco anos. Foi iniciado no ano letivo 91/92, e vai até 1996. Esta primeira parte visa basicamente focalizar a seqüência das disciplinas essencialmente contábeis. a orçamento para a primeira parte e de $U \$ \$ 3,25$ milhões.

\section{Alguns objetivos deste projeto visam:}

- Os estudantes deverão tornar-se "pensadores críticos" para ter um papel mais ativo no processo de aprendizagem. Eles deverão desenvolver a capacidade de auto-iniciativa de descobrimento que permita um processo de aprendizagem continuo e de crescimento na sua vida profissional. Para que isto aconteça, o currículo deve enfatizar muito mais sobre métodos e habilidades para questionar, analisar, julgar e tomar decisões.

- As exigências de educação geral e desenvolvimento das habilidades dentro desta educação geral devera ser mais bem integrada para alcançar e reforçar a opção principal do campo de estudo - no caso, a Contabilidade. Por exemplo, após ter aulas de introdução á Psicologia, os estudantes deveriam ter contatos com diversos problemas nesta área enfrentados no ambiente profissional da Contabilidade e ser encorajados para aplicar os conceitos aprendidos nos problemas relatados.

- O currículo contábil deverá estar integrado, usando uma estrutura conceitual que "encurtasse caminho" das subespecializações da Contabilidade, enfatizando a informação contábil e a sua divulgação na sociedade.

- O fundamento do curso de Contabilidade (a espinha dorsal) devera ser mais conceitual e menos técnico, visando produzir uma profunda compreensão das relações entre a Contabilidade, o mundo dos negócios e a sociedade. 
- Às fronteiras de conhecimento vencidas através da pesquisa deverão ser mais rapidamente incorporadas no processo de aprendizagem dos estudos da Contabilidade.

- Deverá ser enfatizados o trabalho conjunto entre acadêmicos e a comunidade profissional para desenvolver um ambiente de aprendizagem na universidade, onde, mais representativa em tecnologia e somando-se as características reveladas pelos profissionais, será criado um extraordinário material para uso em sala de aula.

O Currículo proposto é composto de quatro partes: educação geral, educação geral em negócios, educação contábil geral e educação contábil avançada. A seguir apresentamos $\mathrm{O}$ currículo proposto para quatro anos, enfatizando em itálico as disciplinas contábeis:

\section{Primeiro Ano}

\section{Primeiro Semestre}

Composição (Inglês)

Cálculo

Ciências Físicas e Biológicas

Microeconômia I

Psicologia

Língua Estrangeira

Introdução a Contabilidade I

Microeconômia II

Estatística Econômica

História

Ciência Política

\section{Segundo semestre}

Discurso/Comunicação

Álgebra Linear

Ciências Físicas e Biológicas

Microeconomia I

Sociologia

Língua Estrangeira

Segundo Ano

Introdução a Contabilidade II

Sistemas de Informações Gerenciais

Laboratório Contábil/Seminário

Culturas Não-Ocidentais

Belas Artes

\section{$\underline{\text { Terceiro Ano }}$}

Contabilidade e o Processo

de Decisão

Evidenciação e Mensuração

Contábil

Laboratório Contábil/Seminário

Lógica

Finanças

Negócios e Técnicas de Escrita
Sistemas de Controle Contábil

Instituições Contábeis e

Legislação

Laboratório Contábil/Seminário

Ética

Comportamento Organizacional

Tecnologia e produção 
Auditoria

Laboratório Contábil/Seminário

Marketing

Legislação em Negócios

Eletiva

Eletiva

\section{Quarto Ano}

\author{
Pratica Contábil \\ Estratégia e Política de Negócios \\ Eletiva \\ Eletiva \\ Eletiva \\ Eletiva
}

De maneira geral, este currículo objetiva que a seqüência das disciplinas contábeis básicas possa desenvolver nos estudantes habilidades em indagar, analisar, julgar e tomar decisões. A estrutura conceitual é desenvolvida considerando "contratos" entre duas ou mais partes.

A Introdução a Contabilidade, ministrada em um ano, introduz os conceitos de negócios, a estrutura dos contratos, a importância da informação para as partes contratantes e o papel central da Contabilidade em prover informaçõeS e facilitar as tomadas de decisões. Em termos pedagógicos, este curso propicia que o estudante trabalhe independentemente e em grupo para analisar as relações que dão base para os contratos.

Como um exemplo, considerando contrato dentro de uma empresa, podem ser citados os acordos cobrindo as compras de bens e Serviços de fornecedores, vendas a clientes, relações com empregados, relações com os bancos, mercado de ações etc. As partes envolvidas no contrato confiam em informação financeira e/ou não financeira para fazer tais acordos.

Com base neste curso introdutório de Contabilidade, cinco cursos, em seguida, oferecem um aprofundamento nos aspectos pertinentes a Contabilidade: Contabilidade e o Processo de Decisão, Evidenciação e Mensuração Contábil, Instituições Contábeis e Legislação, Sistemas de Controle Contábil e Auditoria.

Para ilustrar a organização lógica da seqüência proposta, vamos considerar uma atividade de empréstimo de um banco comercial. Suponha que una empresa esteja procurando um empréstimo bancaria para expandir suas operaçõeS. Assim, num contrato de empréstimo, a empresa e um banco concordam nas condições discutidas, onde o banco se compromete em emprestar (uma parte) e a empresa (a outra parte) se compromete em pagar no prazo combinado.

Este acordo de empréstimo foi possível, após a empresa e o banco tomarem decisões. Estas decisões se baseiam em muitos tipos de informações incluindo a informação que a empresa concedeu ao banco e vice-versa.

O papel da contabilidade é prover informação que dê suporte para esta operação de empréstimo. Assim, o primeiro curso, a Contabilidade e o Processo de Decisão, examina os conceitos comportamentais relacionados as decisões dos contratantes e o papel da informação nestas decisões. Em seguida, a disciplina Evidenciação e Mensuração Contábil considera as características e a comunicação da informação que influenciam o processo de tomada de decisão. Em princípio, o fluxo de informação entre as partes contratantes poderia estar completamente descrito como parte do contrato do empréstimo. Na pratica, os padrões e métodos contábeis foram desenvolvidos para facilitar os fluxos de informações. O terceiro curso, Instituições Contábeis e legislação, examinam o ambiente institucional, regulatório e legal que envolve a informação contábil.

O currículo de Contabilidade, conforme a proposta em análise, deve tam.bem considerar os objetivos conflitantes das partes do contrato. Por exemplo, a empresa poderia preterir usar os recursos emprestados para investir num projeto de risco, enquanto o banco poderia preferir um projeto tendo um risco menor. Prover informações para controlar o comportamento da empresa é obtido no quarto curso, Sistemas de Controle Contábil. o segundo aspecto levantado do conflito de objetivos das partes contratantes é a 
manipulação da informação vinda de uma parte para outra. Contadores podem reduzir os efeitos destas manipulações por um terceiro agente envolvido nesta operação. Este aspecto de Contabilidade é examinado pelo quinto curso, a Auditoria que dá maior credibilidade às informações contábeis.

Indo mais adiante, o currículo deve dispor de meios flexíveis para introduzir materiais que realçarão a aprendizagem do estudante, sem criar embaraços para as disciplinas acima referidas. Assim, para operacionalização desta meta o currículo inclui os cursos continuados de Laboratório Contábil/Seminários, utilizando-se também de especialistas que podem não ser os professores.

Estes cursos ao nível de laboratório serão integrados com outros componentes do currículo. Por exemplo, as aplicações de um software tutoriais podem ser programados a priori para ser aproveitado em outra matéria do currículo. A prática de negociação no laboratório pode ser oferecida imediatamente antes de uma disciplina que requer habilidadeS nesta área. Assim, analisando as habilidades necessárias em outros cursos, os seminários e as práticas no laboratório podem facilitar a continuidade e a integração de conhecimento e habilidade apresentados no currículo.

\section{3 universidade Estadual de Kansas}

O estado de Kansas dispõe de duas grandes universidades publicas, além de outras menores. Além da Universidade de Kansas onde estivemos

sediados, tivemos contato com a Universidade Estadual de Kansas, Manhattan, que esta também implantando importantes mudanças no ensino da contabilidade. Estas mudanças estão sendo suportadas por um orçamento de $U \$ \$ 334.000$.

Esta universidade estabeleceu três objetivos gerais para dar base às mudanças curriculares e pedagógicas:

- Prover aos estudantes de contabilidade conhecimentos técnicos e profissionais para formar a base para uma carreira contábil bem sucedida.

- Prover aos estudantes de Contabilidade habilidades necessárias para implementar seus conhecimentos no ambiente profissional contábil. (Estas habilidades incluem capacitação na 1) eficiência da comunicação (ambas, escrita e falada), 2) na capacidade de analisar e resolver problemas, 3) em lidar eficientemente com outras pessoas e 4) em aprender novas idéias e técnicas que são encontradas apos os estudantes terminarem sua educação formal.

- Atrair e manter estudantes com talentos exigidos para ser bem sucedido na profissão contábil.

Esta universidade entende que de maneira geral a seqüência das disciplinas e tópicos praticados na maioria dos cursos de Contabilidade não propiciam uma pedagogia adequada para sua aplicação. A principal talha da atual abordagem seria que não se está munindo os estudantes de um adequado entendimento dos conceitos mais simples ensinado a priori para passar então aos mais complexos. Assim, há necessidade de se ter uma base racional anterior para se passar a itens mais complexos.

A falta de atenção para a seqüência do conteúdo causa aos estudantes problemas que se agravam com mais informações que eles não podem absorver. Como resultado, os estudantes acabam memorizando sem uma base suficiente para desenvolver uma coerência na estrutura do conhecimento. Dessa forma, a seqüência lógica do conteúdo da estrutura curricular é o ponto básico da proposta desta universidade. A seqüência curricular é dividida em níveis:

Caderno de Estudos no07, São Paulo, FIPECAFI - Outubro/1992 


\section{Nível Introdutório}

- numa seqüência de dois cursos; começa com tópicos administrativos;

- ensina alguns conceitos contábeis dentro do contexto de Jogos

- de Empresas e Negócios.

\section{Nível de Controle e Processo Contábil}

- focaliza a captação, registro, sumarização e controle das informações;

- tem como base a Contabilidade de Custo, intermediaria, Sistema de Informação Contábil e Auditoria;

- utiliza-se de laboratório com Computador e outras ferramentas modernas de ensino.

\section{Nível "âmago" da Contabilidade}

- Historia e Teoria Contábil Relatórios Financeiros;

- Imposto de Renda;

- contabilidade Gerencial para controle e tomada de decisões;

- Princípios de Auditoria.

\section{Nível de Pesquisa}

- curso de pesquisa financeira e imposto;

- trabalhos visando a auto-aprendizagem; técnicas de análise de casos e apresentação

- habilidades interpessoais.

\section{Nível de Especializacão} cursos de Auditoria e Relatórios Financeiros, Impostos e Contabilidade Gerencial

- cursos híbridos

- cursos de Análise de Sistemas

- outros cursos

\section{Alguns Dados Quantitativos dos Cursos de Contabilidade}

Em termos de cursos de Graduação há aproximadamente 700 escolas nos Estados Unidos que oferecem curso de Contabilidade, sendo que dois terços delas estio instaladas em campi com menos de 11.000 alunos inscritos.

$\mathrm{Na}$ década de 80, conforme dados fornecidos pelo próprio governo americano (11), 50.000 estudantes, em média, obtiveram seu grau de bacharel Ou Contabilidade, representando entre 4 e $5 \%$ de todos os estudantes que se formaram.

Nesta década tem crescido substancialmente a participação da mulher na profissão contábil. Conforme 05 dados levantados pelo (06), em meados da década de 70, apenas 14\% dos bacharelados eram do sexo feminino. No final da década de 80 este numero subiu para $50,5 \%$, passando á frente do numero de homens.

Em termos de Pós-graduação, aproximadamente 6.000 novos mestres em contabilidade são formados por ano.

Ainda que para nós, brasileiros, possa ser um número elevado de mestres que alcançam este grau a cada ano (em torno de $12 \%$ dos graduados), nos Estados Unidos é considerado fraco em relação a outras áreas (onde em geral $30 \%$ dos bacharéis terminam o mestrado) e em relação á própria escola de Administração de Negados, cujo percentual dos bacharéis que concluem o mestrado é de $36 \%$.

Há uma diversificação de mestrados em Contabilidade nos Estados Unidos. O mais comum e o MBA (Mestrado em Administração e negócios de Contabilidade) seguido, em ordem decrescente, pelo Mestrado 
em ciência -Contabilidade, Mestrado em Contabilidade, Mestrado para o Profissional Contábil e outras denominações.

Quanto aos programas de doutorado, há aproximadamente 80 escolas que os oferecem com concentração em Contabilidade. [Cerca de 160 pós-graduandos estão obtendo o titulo de doutor (Fh.D] por ano, o que da uma média de dois por universidade). Todavia, considerando só os últimos cinco anos, esta media aumentou consideravelmente, passando de 200 (35).

Conforme o Guia dos Professores de Contabilidade, (35), até o inicio desta década as universidades americanas já formaram 4.281 doutores com concentração em Contabilidade, sendo que nos últimos cinco anos obtiveram o titulo de doutor?

\begin{tabular}{|c|c|c|c|c|}
\hline \multirow[t]{2}{*}{8} & \multirow{2}{*}{87} & \multirow{2}{*}{$\begin{array}{c}88 \\
214\end{array}$} & 89 & 90 \\
\hline & & & 206 & 86 \\
\hline
\end{tabular}

As universidades que mais contribuíram foram:

$\begin{array}{ll}\text { 1)Illinois } & 294 \\ \text { 2)Texas } & 200 \\ \text { 3)Missouri } & 156 \\ \text { 4)Michigan } & 142 \\ \text { 5)Arkansas } & 141\end{array}$

\section{Aspectos Sobre a Metodologia de Ensino}

\subsection{Método de Caso}

Com exceção de Contabilidade Introdutória, utiliza-se constantemente no curso de Contabilidade o método de caso. Há disciplinas que chegam a desenvolver um caso por aula. Esta sistemática é ainda mais intensa na pós-graduação.

Os professores, normalmente, defendem este método, alegando que os estudantes necessitam refletir constantemente sobre problemas reais já ocorridos, ampliando sua capacidade para soluções futuras.

O método de caso foi desenvolvido em Harvard nos anos 20. A maioria das universidades começou a utilizar este método nos anos 50, nível da pós-graduação. A Universidade de Kansas foi à pioneira nos Estados Unidos em introduzir esta metodologia no curso de graduação.

um aspecto importante deste método, segundo alguns professores na área contábil, é que os estudantes aprendem sem receber tudo "mastigado". A ênfase é o desenvolvimento pessoal, compartilhandose idéias e avaliando-se outros pontos de vista.

Para alguns estudantes, esta metodologia pode ser frustrante especialmente para os de Contabilidade acostumados a obter respostas exatas para os problemas. Podem ainda ocorrer colocações em que estudantes achem, no final do curso, que não aprenderam muito em termos de destreza. Todavia, os professores alegam que os estudantes ganham potencial, discernimento e maturidade nem sempre visíveis ou mensuráveis naquele momento. Alegam ainda que os alunos aprendem a detectar o que e relevante para uma decisão particular (isto e importante se compararmos com uma situação em um livro-texto onde não ha informação irrelevante, sendo que não e isto que o estudante ira enfrentar no mundo real)

Conforme Anthony e Reece (01.) os casos são de grande valor no processo educacional como base de discussão em classe. Os casos não são propostos necessariamente no sentido de ilustrar maneiras 
corretas ou incorretas de administrar um problema. A habilidade no tratamento da Informação contábil pode ser adquirida somente através de experiências. Pensando num caso e levando este caso para uma discussão informal, em grupo, na sala de aula, provoca-se a ação do estudante: analisar o problema, avaliar os diversos fatores nele envolvidos, fazer cálculos, tomar posição, e assim por diante. E solicitando do estudante que exponha o seu ponto de vista, defendendo-o, entendendo e avaliando os argumentos de seus colegas e decidindo qual dos argumentos é o mais forte, que se obtém bons resultados no processo de ensino. O exercício desta pratica ajuda a desenvolver a capacidade e o entendimento do estudante; de fato, muitos educadores acreditam que realmente partes importantes de uma matéria contábil só podem ser aprendidas através de algum tipo de experiência concreta e não meramente ouvindo ou lendo o assunto.

Em geral, os casos são previamente preparados pelos estudantes para, em seguida, ser discutidos em sala de aula com orientação do professor que irá usar seus recursos didáticos para melhor proveito do estudante.

\section{Exemplo de Estudo de Caso.}

Para melhor ilustração, vamos reproduzir o estudo de caso aplicado numa segunda aula do curso de Contabilidade Intermediaria em determinada universidade. o caso é para rever alguns conceitos aplicados em Contabilidade Introdutória e introduzir novos conceitos para debates.

\section{O caso do Barão Coburg}

Há muito tempo atrás um senhor feudal tinha uma pequena província na Europa. Este senhor, conhecido como Barão Coburg, vivia num castelo no alto de urna colina. Era responsável pelo bem estar de muitas famílias que trabalhavam na terra que circundavam seu castelo.

Cada primavera, quando a neve começava derreter. o barão tinha de decidir como ia propiciar meios de sustentar todos aqueles camponeses e suas famílias durante um ano.

Numa primavera, o barão estava pensando sobre o próximo plantio e sustento daquelas famílias: "penso que 20 hectares da minha :erra. onde são cinco barris de trigo por hectare, serão suficientes para suprir de trigo todos os camponeses até o final do próximo Inverno". Resolveu. então, chamar dois dos melhores camponeses para administrar seu empreendimento: Ivan e Frederico.

Reunindo-se com ambos, na sala de negócios do seu castelo, o barão disse: "IVan, você cultivara uma área de 23 hectares de terra e Frederico os 10 restantes. Eu darei para você, Ivan, 20 barris de semente de trigo e 20 quilos de fertilizantes (vinte Kilos de fertilizantes tinham o valor de dois barris de trigo) .Darei para você Frederico 10 barris de semente e 10 quilos de fertilizantes. Darei a cada um de vocês um boi para puxar o arado, mas vocês terão que negociar com o Senhor Feliciano, 'o construtor de arados', a aquisição dos arados necessários. Os bois têm três anos de idade e nunca foram usados na lavoura, sendo que estes animais, bem cuidados, trabalham ate dez anos. Cuidem bem deles, pois um boi vale 40 barris de trigo. Voltem no próximo outono para prestação de contas, não esquecendo que eu quero junto com a colheita os bois e os arados".

Ivan e Frederico reverenciaram o barão e deixaram o salão de negócios, de posse dos bens prometidos pelo carão, bastante apreensivos,

Passada a colheita, ambos retornaram ao salão de negócios do barão para a prestação de contas com o seu senhor. Ivan foi o primeiro a falar:

"Meu senhor, eu entrego o boi que foi utilizado muito pouco, um arado bastante danificado e 223 barris de trigo. Infelizmente, devo ao senhor Feliciano o construtor de arados 3 barris de trigo pelo arado que adquiri na ultima primavera. Como o senhor já sabe, usei todo o fertilizante e a semente que me foram 
adiantados. Como o meu senhor pode também se lembrar, o senhor tomou adiantado 20 barris da minha colheita para seu uso pessoal"

Frederico falou em seguida: "Aqui, meu senhor, esta o boi parcialmente utilizado na aragem da terra; aqui esta o arado, em bom estado, pelo qual já paguei ao senhor Feliciano o construtor de arados' 3 barris de trigo da minha colheita; aqui está ainda 105 barris de trigo. Lembraria ainda ao meu senhor que usei totalmente a semente e o fertilizante adiantados, e que o meu senhor tomou 20 barris de trigo a varios dias atrás para a sua propria mesa. Creio, se o senhor me permite,que. o arado.Será útil-ainda para mais duas estações".

Feliz, o barão abençoou os dois camponeses que, reverenciando-o, deixaram o salão de negócios do palácio.

Aqui você entra na estória:

1) Prepare um Balanço Patrimonial para cada camponês em duas colunas, contendo os dados do inicio e do fim da estação plantio. Prepare também a Demonstração do Resultado do exercício.

2) Qual dos camponeses foi o mais bem sucedido?

3) Relacione este caso com a estrutura teórica dos princípios contábeis.

Com base na discussão deste caso, o professor desenvolve: OS objetivos das Demonstrações Financeiras; características qualitativas das Demonstrações Financeiras; conteúdo dessas demonstrações; evidenciações princípios contábeis etc.

\subsection{Prática "versus" Teoria}

No inicio do curso, quase sempre, é entregue para cada aluno uma programação "“aula-por-aula"” onde o estudante conhece antecipadamente o assunto que será tratado em cada aula, bem como a bibliografia concernente. Assim, o aluno vira a aula tendo estudado previamente o tema que será abordado.

Além dos temas relacionados por aula, há a solicitação de exercidos e casos que deverão ser entregues nas respectivas aulas. Estes exercícios ou casos são recolhidos pelo professor que os corrige, devolvendo-os normalmente na aula seguinte (fazendo parte da avaliação do estudante), com comentários sobre os erros cometidos.

Dessa forma, ao entrar em sala de aula, o estudante já estudou e fez os exercícios solicitados, permitindo ao professor uma abordagem didática apenas sobre os temas mais complexos. Isto favorece o desenvolvimento de uma quantidade muito grande de matéria, podendo-se abranger muito mais tópicos num semestre do que aquilo que normalmente fazemos.

Isto também permite que a aula seja bastante pratica, concentrando-se boa parte do tempo na resolução de exercidos e discussão de estudo de casos. É normal, portanto, passar aulas e mais aulas trabalhando em cima de casos práticos e fazendo exposições teóricas a medida que os problemas vão surgindo. 
Em algumas disciplinas há a obrigatoriedade de o aluno adquirir um disquete onde já está programada uma bateria de atividades, bem como orientações práticas, compondo o processo de aprendizagem.

O que se observa em boa parte das universidades americanas é que normalmente as aulas de Contabilidade fl80 são ministradas com extensas e pormenorizadas exposições. o professor é um "“facilitador"' no processo de aprendizagem do aluno. Ele dá uma completa assistência, desde a indicação do livro texto e os demais materiais, explicando e debatendo os pontos mais complexos corrigindo e dando nevas tarefas, até as considerações sobre as avaliações, indicando as melhores respostas ou soluções.

Na verdade, Instrumento fundamental de ensino da Contabilidade e o livro texto, pois tudo gira em torno dele. ai a preocupação das editoras em apresentarem cada vez mais "pacotes" atraentes no sentido de melhor atender esta sistemática de ensino. Mais à frente deste trabalho, no segmento Livros Textos (pacotes) evidenciamos o exemplo de uma editora que propicia pacotes com quase 23 itens que acompanham o livro texto.

O mercado de livros contábeis e altamente competitivos nos EUA. Pode-se encontrar muitos livros para cada titulo. Por exemplo, na área de Contabilidade Introdutória (Financial Accounting, Accounting Principies) há dezenas deles, com muitas atrações em cada capitulo, tais como: metas a serem atingidas, capitulo introduzido com um exemplo real e relevante para motivar o estudante; estilo gráfico que torna a aprendizagem mais clara, precisa e de fácil entendimento: disposição especial de textos nas paginas que atrai a atenção para os conceitos mais importantes; diversificação de ilustrações e em cores; exemplos com empresas reais aplicando-se os conceitos e a teoria aprendida; no final de cada capitulo ha sumários, palavras chaves, avaliação das metas alcançadas, testes de auto avaliação, demonstração de problemas e uma bateria de exercícios com algumas soluções etc.

Assim, de posse desses instrumentos didáticos e considerando que o aluno normalmente estuda período integral, dedicando-se exclusivamente a universidade (tendo tempo disponível e material de muito bom nível), o professor conduz a aula dando uma ênfase muito grande a parte pratica do curso, propiciando debates ativos sem ser um "vomitador de matéria".

\subsection{Breves Comentários Sobre Algumas Disciplinas.}

\subsubsection{Contabilidade Introdutória.}

Normalmente com o titulo de Contabilidade Financeira, a Contabilidade é introduzida, em diversas universidades, em turmas grandes (auditório), com quatro aulas semanais, sendo que ha uma subdivisão de pequenas turmas para mais duas aulas semanais com assistentes. Em outras universidades o ensino desta disciplina e ministrado em grupos menores, através do uso da televisão, com assistentes para complementar o processo de ensino.

O volume de matéria ministrado nesta disciplina e extremamente grande, sendo que um livro texto em torno de 800 paginas e praticamente esgotado no semestre. isto 50 e possível pelo fato de existir a leitura previa e a resolução dos exercícios antecipada, com entrega obrigatória antes do inicio da aula. Pelo fato de o assunto que vai ser tratado já estar digerido pelo aluno, o professor aborda apenas os pontos essenciais, não entrando no trivial que, pressupõe-se já foi absorvido no estudo pré-aula e na resolução dos exercícios.

Assim, por exemplo no terceiro encontro do curso, numa "dobradinha", e abordado tema Registros Contábeis, onde o professor expõe/debate os seguintes assuntos: Contabilidade como Sistema de Informação, alguns princípios Contábeis, Tipos de Transações, efeitos dessas transações na Equação Contábil, Contabilidade por Balanços Sucessivos, Sistema Razão. Escrituração no Diário, as principais contas de Ativo e Passivo, Patrimônio Liquido. uma rápida abordagem de Receita, Despesa, Debito e Credito, Método das Partidas Dobradas, Balancete de Verificação, tipos de erros comuns nos Lançamentos Contábeis e Analise das Transações Contábeis.

Caderno de Estudos nº7, São Paulo, FIPECAFI - Outubro/1992 
O assunto pode ser debatido novamente com os assistentes. E comum na aula que preceder a prova bimensal, haver uma revisão de toda a matéria dada naquele período; na aula seguinte as provas, serão apresentadas as soluções corretas, onde ainda poderá haver comentários sobre este assunto.

Nesta velocidade e ministrado uma visão geral de todo o processo contábil, em detalhes, até as Demonstrações Financeiras, incluindo a Analise de Balanços dessas demonstrações, conceitos de Custos, Matemática Financeira, Mercado de Capitais, Auditoria e ate mesmo Fluxo de Caixa. A razão de se ministrar uma visão geral é que este curso se destina também a estudantes de outras áreas que precisam ter uma base contábil.

\subsubsection{Contabilidade Intermediária}

Ha bastante livros de Contabilidade Intermediaria nos Estados unidos, todos eles com mais de mil paginas (em media 1.300). O conteúdo desses livros e bastante semelhante e de maneira geral abrange: Relatórios Contábeis, Princípios Contábeis, Revisão do Processo Contábil, Balanço patrimonial, Demonstração do Resultado do Exercido, Demonstração do Fluxo de Caixa, Evidenciação, Juros Compostos, Caixa e InvestimentoS Temporários, Contas a Receber, Inventario, Ativo Permanente, Depreciação, Intangíveis, Passivo Circulante, Passivo de Longo Prazo, Financiamentos, Investimento, Patrimônio Liquido (subdividido em 3 capítulos), Demonstração de Origens e AplicaçõeS de Recursos, Leasing, Contabilidade Orçamentária, Contabilidade de Fundos, Contabilidade de Impostos, Contabilidade em Nível Geral de Preços e Analise Das Demonstrações Financeiras.

Esta disciplina é ministrada imediatamente após a Contabilidade Introdutória, sendo normalmente apresentada em dois semestres.

Num curso de Contabilidade Intermediária que tivemos a oportunidade de assistir, a titulo de exemplo, foi solicitado um pacote didático composto de: Livro Texto (36) com 1.400 paginas, Guia do Estudante (contendo "dicas" e informações adicionais - em media 700 paginas), Livro de Exercícios e Casos (em média 450 paginas) e um Guia de prática Contábil por computador (incluindo um disquete com um programa). Além deste pacote, o aluno devera adquirir dois volumes contendo os pronunciamentos (FASB)

Contábeis que norteiam Contabilidade nos Estados Unidos (com quase 2.000 paginas, recomendada ainda uma assinatura do The Wall Street Journal, senão comum o professor comentar em saia de aula alguns dos seus artigos voltados para a Contabilidade).

Normalmente um pacote como este custa quase USS 200. Ainda que seja elevado para o estudante, considerando-se que ha outras matérias e livros para comprar, há a vantagem, enquanto a editora não muda a edição, de se vender o pacote de volta as livrarias da universidade no final do curso por um pouco mais que a metade do preço pago na aquisição. As livrarias, por sua vez, colocam a venda para o semestre seguinte os livros usados, reduzindo assim o custo para os estudantes na aquisição de livros.

Como já dissemos, também nesta disciplina, não há uma exposição ampla da matéria. o professor faz rápidos comentários sobre o assunto proposto e então inicia a discussão de exercícios e casos, complementando as explicações necessárias, tornando a aula a mais pratica possível. Os exercícios e os casos são cem abrangentes e atraentes como o exemplo que demos no item Método de Caso, com o Caso do Barão Coburg.

\subsubsection{Workshop}

Não conseguimos encontrar uma palavra adequada que pudesse traduzir o significado exato de Workshop (os dicionários traduzem como Oficina). Em alguns pontos deste trabalho, como no segmento Algumas Propostas de Mudança nos Programas de Contabilidade, tratamos esta palavra como Laboratório Contábil/Seminário.

Caderno de Estudos n07, São Paulo, FIPECAFI - Outubro/1992 
Os workshop são mais comuns em nível de pós-graduação, embora haja universidades que trabalhem em nível de graduação e outras instituições que estejam implantando este tipo de atividade nas reformas curriculares propostas também em nível de graduação.

De maneira geral, eles são constituídos de seminários práticos onde são convidados profissionais especializados em determinadas áreas contábeis, professores de outras universidades e ate de outros paises, especialistas em assuntos que estão ligados a área contábil e assim sucessivamente.

Quando em nível de pós-graduação, e comum a participação semanal de todos os professores do departamento bem como alunos, propiciando interessantes debates entre estes alunos, professores e os especialistas convidados.

Todavia, outras experiências interessantes são observadas nestas reuniões. Por exemplo, e comum o aluno expor seu projeto de tese ou dissertação para a apreciação dos participantes do Workshop, que por sua vez darão sugestões e contribuições para o trabalho em debates.

Tivemos oportunidade de assistir num desses Workshop a uma proposta de dissertação (4) para o grau de doutorado, cujo autor o:tava na primeira capa: "agradecemos aos Workshop da Universidade de Oklahoma, Universidade do Texas/Tech e a Universidade da Indiana pelos importantes comentários para este trabalho". Era o quarto Workshop de que ele participava, onde a referida proposta de dissertação era submetida para ser enriquecida com sugestões; havia a possibilidade ainda, de um quinto (Universidade de Minnesota), a que o autor estava vinculado.

Estes Workshop também são utilizados para recém-titulados exporem seus trabalhos (tese ou dissertação), tendo seu potencial avaliado por uma comissão, como um candidato a professor no departamento. Assim, é comum se ter contato com doutores (ou em rase de defesa de doutoramento) de outras universidades americanas.

\subsubsection{Outras Disciplinas do Curso de Graduação}

No que tange a Contabilidade de Custos/Gerencial, a didática e bastante semelhante com o que já foi dito em relação as Contabilidades Introdutória e Intermediária. De maneira geral os conceitos introdutórios de custo não são abordados mais neste curso, pois já foram tratados nas duas disciplinas que a antecederam.

A exposição por parte dos professores são reduzidíssimas, dando-se ênfase á parte pratica, como discussão das soluções dos casos/exercícios. Num curso que assistimos nesta área, só para exemplificar, observamos a professora abordar todo o conteúdo de Custo Padrão (conceito, cálculo, variações, análise) em menos de quarenta minutos, dispensando algumas aulas para debates de pontos específicos detectados na elaboração dos exercícios feito em casa pelos alunos.

Dos livros de Contabilidade de Custos, Horngren (41) continua sendo o mais adotado, já na sua sétima edição. Normalmente, os dois primeiros capítulos não são aplicados (capítulos introdutórios) e os capítulos restantes são quase integralmente, normalmente, mas não na ordem seqüencial ordem que o Livro dispõe. Como já era do nosso conhecimento, há uma ênfase notória em métodos quantitativos (matemática e estatística), que não é peculiaridade do autor citado, mas da teoria que ensina ou escreve sobre Contabilidade de Custos e Gerencial.

A Contabilidade Avançada, cuja metodologia é voltada mais para seminários desenvolvidos pelos próprios alunos e é dada ênfase ainda maior em casos práticos, normalmente e composta dos seguintes tópicos:

problemas econômicos e contábeis nas combinações de empresas; grupo de empresas; consolidação das demonstrações financeiras antes e depois da aquisição; tomada de decisão e pesquisa contábil; matriz e 
filial; a contabilidade e as operações internacionais; a formação e extinção de sociedade governamental; contabilidade para empresas sem fins lucrativos; avaliação de empresas; franquias e consignações; etc.

O curso de Sistemas de Informações Contábeis, de maneira geral, ensina o aluno a se introduzir, analisar e controlar um sistema de informação contábil; e planejado para prover conhecimento e ferramentas computacionais de maneira que o estudante seja preparado para ser um proflssional bem-sucedido tanto quanto contador/auditor, como também para gerenciar. Os tópicos cobertos neste curso incluem tecnologia computacional, controle interno num ambiente computacional. auditoria computacional, analise de sistemas e design, sistemas de banco de dados e aplicações de sistemas específicos. Este curso, a base de seminários, requer conhecimentos básicos em computador (pelo menos duas disciplinas em computação cursadas antes) . Um dos livros textos mais usados e o do Cushing (42)

Em relação a Auditoria, também são utilizadas as leituras previas que sustentaram as discussões em cada sessão. Casos simulados são constantemente usados orientando a operacionalidade e as decisões ce Auditoria. Um livro-texto bastante adotado e Auditing: "an integrated approach", de Alvin Arens e James Loebbecke (Prentice Hall) Normalmente são discutidos nesta disciplina casos de ética, o que você faria (considerando o código de ética) e o que efetivamente foi feito.

Das demais disciplinas, o que e considerado bastante relevante esta na área de impostos, onde pelo menos duas matérias são oferecidas: contabilidade tributaria, contabilidade do imposto de renda, pesquisa em impostos etc.

\section{O Uso do Computador}

\subsection{O Microcomputador nas Universidades}

Ha quem diga que o microcomputador e um símbolo de mudança nos campi universitários.

No que tange a Business Schools realmente esta mudança tem sido de grande relevância.

Em 1980 a UCLA (Universidade de Califórnia - Los Angeles) pesquisou 37 Business School. (21) e encontrou computadores sendo usados fundamentalmente para modelos Matemáticos e Estatísticos, Nenhuma escola tinha microcomputadores disponíveis para uso geral.

Outra pesquisa feita também pela UCLA (19) em 1990, dez anos depois, abrangendo 145 Business Schcool. credenciadas encontrou em medra 200 microcomputadores disponíveis em cada escola pesquisada. Em média o índice Estudante/MicrocomputadOr para estas escolas era de 37 por 1.

Outra pesquisa realizada em 1990 (20) sem incluir microcomputadores usados pelos docentes e staff, constatou que o índice Estudante/Microcomputador em cada Business School disponível em laboratório e sala de aula, era de 45-46 por 1.

Estudantes proprietários de microcomputadores constituem-se em outro indicador que tem mudado bastante. Muitas escolas têm aumentado relevantemente sua "força de computador" estimulando OS estudantes a terem o seu próprio micro. A pesquisa EDUCOM (20) estima que $29 \%$ dos estudantes de universidades privadas tem seu próprio computador.

Em termos de BusIness School, esta tendência é bastante interessante. A pesquisa da UCLA) (19) relata que em média, $22,8 \%$ dos alunos de graduação têm seus próprios micros, enquanto $39,7 \%$ dos estudantes de Mestrado também os tem.

Normalmente, os micros são vendidos para estudantes em condições bastante favoráveis rio que tange ao preço e as condições de pagamento. Por exemplo, por pouco mais de mil dólares estudante compra 
o seu computador 386 completo, incluindo hard driver e impressora, podendo pegar em prestações tão baixa como de 20 dólares por mês.

Se ele não puder (ou não quiser) comprar o seu próprio micro, pode usá-lo com muita facilidade e assistência no centro de computação da Business School, ou ainda no centro de computação da universidade, que geralmente funciona 24 horas por dia e 365 dias por ano.

\subsection{Currículo Contábil, a Computação e o Ensino da Contabilidade}

Como já tivemos oportunidade de abordar, há muitas propostas de mudanças radicais dos currículos dos programas de Contabilidade nos EUA para esta década.

Diversas universidades estão empenhadas nesta missão juntamente com a AECC - Accounting Education Change Comission que foi criada para fomentar mudanças na preparação acadêmica dos futuros contadores visando maior sucesso profissional na carreira.

Algumas universidades estão implementando os currículos contábeis protótipo desenvolvido pela EACC, tais como: Rutgers University, University of North Texas, Kansas State University, University of Massachusetts e Brighan Young University.

Outras universidades como The University of Alberta, University of Southern Califórnia e The Uriiversity of Idaho estão independentemente desenvolvendo programas inovativos consistentes com as metas esboçadas pelo AECC. Ainda outras instituições de ensino estão submetendo as suas propostas à apreciação da AECC.

O que se pode deduzir destas propostas e que o computador não e mola que impulsiona as mudanças curriculares nos programas de Contabilidade, mas ele desponta com um status muito mais elevado no ensino, compatível com o exercício da Contabilidade no momento.

O computador revela-se como um poderoso instrumento, capaz de ativar importantes mudanças no ensino, como a substituição 03 instrução através de aulas expositivas pela instrução com base em casos práticos, e ainda propiciar novos métodos de aprendizagem, que motivam e contribuem para um real desenvolvimento do estudante.

Hoje, boa parte dos livros de Contabilidade acorda a informática. E comum encontrar-se em edições mais recentes livros-textos com um pacote de informática anexo, como software, aplicações de planilhas eletrônicas, banco de testes computadorizados, transparências eletrônicas, manual para o estudante fazer exercícios, problemas e casos e ate mesmo desenvolver conceitOs básicos de Contabilidade. No segmento Livros-Textos (pacotes) deste trabalho damos uma idéia dos livros que estão acompanhados destes instrumentos.

Como exemplo, citamos um pacote de Contabilidade Intermediária composto de um Practice SET/DASH II (22) através do IBM-PC onde encontramos diversos exercidos "computadorizados" de Contabilidade. $\mathrm{O}$ processo desenvolve-se através de um sistema contábil para uma empresa especifica e permite ao estudante executar as seguintes etapas:

- revisão e reforço do entendimento das bases mecânicas do sistema de Contabilidade de Custo e de todo o ciclo contábil;

- adquirir experiência com computador:

- ver como o computador pode lidar com um sistema contábil. 
São estabelecidas transações por dois meses, permitindo ao estudante trabalhar através do ciclo contábil manualmente e através do IBM-PC/XT ou compatível. O trabalho e dividido em etapas que podem ser operacionalizadas independentemente, tornando-se mutuamente exclusivas.

Como quase todos os pacotes deste tipo, o estudante não preclsa ter experiência com o computador: o manual anexo da as diretrizes.

A empresa em analise tem seu histórico, desde a sua constituição ate o inicio dos exercícios através do computador. s feita uma descrição do sistema contábil, da política contábil da empresa e de todo o seu ciclo contábil. O processo vai desde os primeiros lançamentos contábeis ate os Relatórios Contábeis, bem como sua analise.

\subsection{A Disputa de Mercado}

Principalmente no meio universitário percebe-se uma luta acirrada entre a BM (e os computadores compatíveis 3M) e a Apple, baSicamente através do Macintosh para ocupar o espaço entre os estudantes e professores universitários.

Apesar do predomínio da IBM e dos compatíveis, observa-se um crescimento da preferência dos estudantes que não se concentram na área da Ciência da Computação pelos modelos da Macintosh.

Os produtores do Macintosh dizem que quando decidiram fazer um novo tipo de computador enfatizaram a facilidade de instalação, a facilidade para aprender a usa-lo e a facilidade do uso do mesmo. Parece que eles realmente alcançaram os se s objetivos, pois além de ser descomplicado, torna-se um PC (computador pessoal) "intuitivo".

Alguns aspectos que estimulam estudantes optarem pelo modelo da Apple no meio universitário:

1. É muito fácil copiar informação e transferi-la para outros documentos.

2. Trabalha-se com imagem (figuras) no visor (na tela), facilitando tremendamente a operacionalidade. Por exemplo, ha uma imagem de uma lata de lixo para se jogar um arquivo que não interessa mais e assim por diante.

3. A instalação e muito simples não se necessitando de um técnico;

4. Não há necessidade de se conhecer palavras técnicas e secretas para operacionalizado. $O$ sistema Macintosh usa palavras familiares, simples de entender, tais como: copie, salve, imprima.

5. Para cada arquivo aberto pode-se dar um titulo sugestivo, amplo como "Exercidos de Contabilidade Gerencial"; normalmente, nos outros computadores não se pode passar de oito caracteres.

6. Ele funciona com um programa chamado HiperCard que foi criado pelo grupo de engenheiros em software da Apple. Este programa permite armazenar, organizar e apresentar informações em novas e melhores maneiras.

7. E melhor para estudantes que têm disciplinas em línguas onde ha acentuação [ortografia] pois os programas que processam textos da Macintosh são universais, sendo possível usar símbolos como crase, acento agudo, acento circunflexo, cê-cedilha etc. 
Há ainda outras vantagens indicadas, principalmente por estudantes que não cursam disciplinas relativas a Ciências da Computação.

\section{Windows}

Baseando-se na experiência bem sucedida do Macintosh, a Microsoft Corporation inventou o Windows 3.0 para computadores que usam MS-DOS tornando-se a operacionalização do IBM e compatíveis IBM mais fácil.

O MS-DOS (Sistema Operacional em Disco - Microsoft Corporation) foi desenvolvido em função dos computadores (PC) da IBM e compatíveis IBM. Este sistema, todavia, e considerado mais difícil para operacionalizar, principalmente para estudantes leigos na área não ligada a Ciência da Computação, sendo necessário memorizar uma série de códigos seqüenciais parta operar o computador.

A aplicação Windows e considerada a maneira mais moderna e mais produtiva para operacionalizar os computadores (PC) 3M e compatível.

Assim como o sistema de imagens ou figuras da Macintosh, ela e considerada um processo intuitivo para a aprendizagem. As imagens ou ícones normalmente em retângulos ou "janelas" aparecem na tela do computador, tornando-se as rotinas automáticas, de fácil seqüência (não havendo necessidade de memorizar os comandos chaves de acesso)

Ainda como o Macintosh, na aplicação do Windows utiliza-se o mouse, um pequeno aparelho movido debaixo da palma da mão que desliza sobre a mesa, permitindo, com simples toques e movimentações, percorrer o comando por toca a tela, evitando-se o uso do teclado.

Com o mouse, num instante chama-se o menu na tela e seleciona-se a atividade desejada. Com ele pode-se "pinçar" um documento desejado para se trabalhar nele e joga-lo de volta no arquivo quando encerrar as operações. Quando se processa um texto, por exemplo manuseando-se o mouse e possível fazer cortes e reproduzir palavras, linhas e parágrafos, da maneira que se desejar, de uma parte do documento para outra ou ainda entre dois documentos.

O sistema operacional Windows (bem como no Macintosh) permite que se trabalhe com multitarefa simultaneamente, não havendo necessidade de sair de um programa para entrar num outro.

Por fim, nota-se a preferência nas universidades pelos sistemas abordados, principalmente porque através deles se vê na tela o mesmo formato e caracteres que serão impressos. Por exemplo, palavras em itálico, ou em negrlto, ou sublinhadas, exatamente como estão na tela serão impressas. Ainda: se fizer um gráfico, ou se quiser ilustrar com um gráfico tipo "pizza", ou usar notas de rodapé, . . .tudo isto será fielmente reproduzido pela impressora (o que nem sempre acontece com o DOS sem o Windows).

\section{Macintosh X IBM}

Ainda que os PCs IBM e compatíveis predominem, nota-se, como já dissemos, no meio acadêmico, um crescimento considerável do Macintosh.

O ponto mais critico dos Macintosh é que por serem produzldos em menor quantidade que seu principal concorrente, são oferecidos no mercado, tanto o computador como os programas e periféricos, a preço mais alto do que o do sistema IBM. 
Por outro lado, observa-se que os leigos em computador não gostam de trabalhar com o "complicado" MS-DOS, comuns ao sistema IBM. A aplicação do Windows, como já vimos, vem resolver este problema.

necessário, todavia, instalar adicionalmente o Windows nos computadores com MS-DOS, exigindo-se que o computador seja mais "potente" para suportar este acréscimo.

Os defensores da Macintosh normalmente dizem que para trabalhar com o windows é necessário um pouco mais de paciência para entender como todas as coisas funcionam, porque sempre há um outro programa acoplado operando simultaneamente.

\subsection{Software}

Normalmente, encontra-se uma infinidade de softwares a disposição dos estudantes de Business, auxiliando o ensino e as pesquisas. Alguns exemplos de $\underline{\underline{\text { softwares }}}$ disponíveis para os IBM e Macintosh são:

Mac: Word, WordPerfect, Excel, Super Paint. Cricket Graph, SPSS, Teach Text, FoxBASE+, HyperCard, Telnet, Quark Press, Wings, Mac Write, MacDraw, Mac Paint, Mac Pascal, MS Fortran, TN3270....

Sistema IBM: FairModel, @Risk, dBase, Enable, Field pack, Flowchart, GMAT, Gaus, Insight, Lotus 1-2-3, Management Scientist, MS-Works, Micro solve, Microstate, Minitab, PC Easy, PC SCA System, PreAudit, QSB, Resume Expert, SCAD, SPSS/PC, Statistix, Storyboard Plus, FEM, Simulator, Turbo Pascal, Turbo Prolog, Value Screen, What's Best, WordPerfect, WordStar, SLP88, MC2, Mona nova,Kermit,Harvard Graphics, FoxBASE+, SAS, Smart ware.

Conforme uma publicação da Addison-Wesley Student Edition (18) alguns dos principais softwares usados pelas disciplinas básicas nas Busiriess School são:

- Principio de Contabilidade

- Introdução a Finanças

- Introdução aos Computadores

- Ciência da Administração

- Estatística em Negócios

- Política de Negócios
Ready-toRum and NewViews

Lótus 1-2-3

Framework II, Lótus 1-2-3, dBase IV

What-If Solver, @Risk, ForeCalc

MINITAB,ForeCalc

Lótus 1-2-3

É importante considerar que diversos softwares na área contábil são específicos de "pacotes" didáticos, que não estão a disposição do estudante, e que deverão ser adquiridos, normalmente a preços módicos, por ocasião da aquisição dos livros textos. Alguns desses softwares são mencionados na relação de Livros Textos (pacotes) adiante.

No que tango às planilhas eletrônicas, softwares mais usado é o Lótus 1-2-3. Todavia, uma interessante pesquisa feita pela software Digest Ratings Report, mostra que o Microsoft Excel 3.0 em termos de programas de planilhas avançadas, possui a melhor avaliação conforme o quadro abaixo:

Ranking

1.

2.

3.

\section{Programa}

Microsoft Excel 3.0

Quatro Pro 2.0

Lótus 1-2-3 3.1
Avaliação (Nota)

8,9

8,4

7,2

Os professores também dispõem de diversos tipos de softwares para auxiliarem as suas aulas. Alguns são oferecidos pelas editoras cujos livros textos são acatados. Outros são oferecldos especificamente para este mercado didático. Só para citar um exemplo, vimos o uso do Storeboard que e um programa muito fácil de se usar para fazer estudo ce caso e outras atividades. No estudo de caso pode-se passar no vídeo a 
estaria usando-se letras coloridas que facilitam a leitura por parte dos alunos e apresentar desenho que e facilmente feito com o uso do rnouse. O programa já e preparado com os nomes dos alunos e com perguntas individuais para os mesmos. O professor prepara um "menu" para o aluno e da algumas orientações antes da aplicação do mesmo no computador. Normalmente o caso fala de uma empresa real que pode ficar numa pequena cidade (ou grande) de determinado estado. Tudo isto esta num mapa dos Estados Unidos que facilitará a visualização por parte do aluno no vídeo. Depois o programa localiza as subsidiárias, tam.bem com auxilio do mapa. Assim o aluno vai fixando dados descontraidamente. Outras ilustrações são apresentadas para contar a historia da empresa. O programa dará os relatórios outros dados e pedira o que o aluno deve fazer, fornecendo planilhas e outras informações orientativas para desenvolvimento do caso.

\subsection{Inteligência Artificial e os "Expert Systems"}

inteligência artificial refere-se ao uso mais ousado dos sistemas computacionais, alcançando os melhores níveis do raciocínio humano. Principalmente as universidades têm realizado experiências baseadas nesta tecnologia em linguagem normalmente chamadas de sistemas computadorizados de quinta geração.

A medida que as aplicações mais praticas de Inteligência Artificial foram desenvolvidas, deu-se origem aos chamados Expert svstems (sistemas especializados), que avançam ao nível mais elevado ia capacidade humana (peritos) em resolver problemas especiflcas com conhecimento e habilidade.

Edward Feiqenbaun, (45), um dos pioneiros nesta área, define um expert svstem como um programa inteligente de computador que usa procedimentos de conhecimento e inferência para resolver difíceis problemas que requerem perícia/habilidade humana para as suas soluções. O conhecimento necessário para se executar neste nível junto com os procedimentos de inferência, origina-se dos melhores peritoS de uma determinada área; assim, os expert systems são programas de computadores com capacidade de resolver problemas altamente específicos por área.

Como exemplo, um robô que se movimenta num almoxarifado necessita conhecer todos os objetivos possíveis no almoxarifado e todas as regras de locomoção, que dizem a ele como desviar dos objetos sólidos, fazer rápidas paradas etc. Na área contábil, por exemplo, um expert systems pode ser preparado para diagnostico de contas á receber, que poderá ser usado para determinar quais contas são recebíveis.

De acordo com a estimativa feita por Newquist (44) em meados da ultima decaia, mais da metade das 500 maiores empresas relacionadas pela Fortune ativamente desenvolvia tais sistemas.

A meta principal dos expert svstems e a de transferir capacidade para aqueles que não estão providos de penda, como e o caso dos estudantes universitários (e também de profissionais) aperfeiçoando a qualidade de julgamento e de decisão e, possivelmente, sua habilidade em resolver problemas gerais.

Atualmente, há escassez de peritos capazes de satisfazerem a futura demanda de aplicáveis no mundo dos negócios, principalmente na área contábil/auditoria. Esta deficiência de pessoal especializado esta propiciando associações (43) entre empresas de auditoria, universidades e firmas especializadas em desenvolvimento de software para estimular as pesquisas nesta área.

\subsection{Ensino da Contabilidade Integrado: Computador, Produção e Administração}

Modernos processos de produção assistidos pelo computador tais como "Flexible manufacturing svstems" (FMS) e "computer-integrate manufacturing" (CIM) estão revolucionando a maneira das empresas produzirem seus bens e a maneira de a contabilidade Gerencial acumular e informar os dados operacionais. 
A IBM tem dado apoio na aplicação do sistema produção com qualidade (Word-class manufacturing) nas universidades, e esta empresa tem feito generosas doações para os centros de produção integrados ao computador cujo projeto é conhecido como "CIM in High School Education Alliance".

Das diversas instituições de ensino que têm implantado este projeto para prover os estudantes de Contabilidade deste excepcional método de ensino (53), uma das mais citadas é o Cerritos College em Norwalk, Califórnia. O centro CIM de Cerritos é formado de modernas instalações, com máquinas de produções automatizadas e a facilidade de um desing de engenharia avançada, que permite ao aluno observar os robôs e outros equipamentos automatizados em ação, lidando com simulações e produção real.

Neste centro há interação entre estudantes de Contabilidade, estudantes de Engenharia de Projetos, Engenharia de Produção, "Marketing", etc. Assim os estudantes de Contabilidade estão envolvidos no recalculo dos custos dos produtos quando modificados pelos estudantes de engenharia. Fazem novos orçamentos e discutem os estudantes de outras áreas decisões a serem tomadas para viabilizar 0 desenvolvimento do novo produto. Relatórios contábeis são produzidos para cada circunstância e o estudante de Contabilidade torna-se parte ativa e vital da administração e produção num sistema integrado.

Novos campi têm utilizado esse sistema de ensino, tais como: Chattanooga State Technical Community Colleqe, El Camino Colleqe, Greenville Technical College, Central Piedmont Comunity College, Lansinq (Michigan) Comunity Colleqe, Illinois Valley Communty College.

\section{Ensino à Distancia e à Eletrônica}

A maioria das grandes universidades e faculdades americanas já esta oferecendo algumas disciplinas ou cursos "à distância", embora graduação completa seja menos comum.

O ensino pode ser transmitido ao vivo, via satélite ou por computador. Existem ainda os "pacotes" prontos em vídeo (tele-cursos) e os cursos em TV por cabo, todos valendo créditos. Esse processo ;a substitui o ensino por correspondência e de certa forma pode ameaçar o ensino do contato face a face.

A idéia e que manter poucos estudantes agrupados ao mesmo tempo numa sala com as portas fechadas eleva consideravelmente o custo do ensino, além de provocar paralisação do processo educacional por ocasião do término do curso.

A University of Mayne (31), por exemplo, contou, no ultimo ano com mais de 5 mil estudantes obtendo credito através do ensino a distância.

A University of Mayne (31), decidiu ir onde os possíveis estudantes estavam, alcançando pontos distantes, formando 12 concentrações em todo o estado (alem dos sete campi atuais) utilizando-se do ensino eletrônico a distância. Por exemplo, neste caso, 1.500 .000 livros já estão listados com informações básicas aos estudantes à distância. Não sendo suficiente os dados pelo computador, o usuário \& distância pode solicitar o livro que será entregue pelo correio em poucos dias.

Aproximadamente 4.000 engenheiros conseguiram avançar obtendo graus mais elevados de estudos, em seus próprios locais de trabalho. Via satélite, da National Technological Univercitv (31), que se tornou uma das maiores universidades na área de engenharia do pais, utilizando professores de 40 outras universidades.

De maneira geral, estes veículos de ensino estão ganhando força nos Estados Unidos, evitando grandes deslocações de pessoas e, sobretudo, propiciando que pessoas que em tese passaram da época de estudar em uma Universidade, tenham novas e exeqüíveis oportunidades de estudar.

\section{Livros -textos (pacotes)}


Ao longo deste trabalho pudemos fazer diversos comentários sobre a aplicação de Livros - textos, abordando sua eficiência, sua relevância no ensino atual da Contabilidade e diversos outros aspectos tais como custos dos livros didáticos, forma de comercio etc.

Neste segmento nos propomos a fazer uma abordagem dos "pacotes" cada vez mais amplos oferecidos pelas editoras americanas.

A titulo de exemplo, trabalharemos com uma editora americana, escolhida aleatoriamente. Faremos uma relação dos livros - textos contábeis de que esta editora dispõe e indicaremos o conjunto de itens que acompanha o referido livro: "o pacote". A editora escolhida e a HBJ. (23)

Apresenta-se em seguida uma lista de itens, por ordem alfabética, que pode compor o Pacote didático que acompanha o livro texto:

01) Aplicações Lótus 1-2-3, ou outras planilhas;

02) Áudio - Tapes;

03) Banco de Testes;

04) Banco de Testes por Computador;

05) Exercícios Pr\&ticos/Casos/Problemas;

06) Guia do Estudante;

07) Guia para Estudo no Computador/exercícios - Versão IBM;

08) Guia para Estudo no Computador/Exercícios - Versão Macintosh;

09) Manual do Instrutor;

10) Manual do Instrutor com Disk;

11) Manual de Soluções;

12) Papeis de Trabalho;

13) Software, IBM ou Macintosh;

14) Testes de Avaliação de Desempenho;

15) Transparências

16) Transparências Eletrônicas;

17) Transparências com Soluções;

18) Vídeos;

19) Outros Itens.

\title{
Livros - textos
}

\author{
Introductions to Colleqe Accounting \\ 2 volumes - 1.555 paginas \\ Gregory W. Bischoff \\ Pacote: 11, 15, 17, 12, 14, 9, 10, 5, 6, 13, 7 e 19.
}

\section{areer Accounting Fundamentals}

559 paginas

Melvim Morgenstein

Pacote: 9, 15, 11, 4, 6, 12, 5, 13, 2 e 19.

\section{Accounting: An Introduction edição revisada}

2 volumes

Nanci Lee

Pacote: 6, 9, 11, 12, 3, 4, 15, 5, 13 IBM, 13 Mac 319.

Principles of Accounting; 5 ed.

1.160 paginas

Paul H. Walgenbach, Ernest I. Ranson e James C. Hamre

Pacote: $11,14,7,15,16,18,6,12,13,5,4$, 8 e 19.

Computer Resoure Guide: Principles of Accounting; 3 ed. 
248 paginas

John W. Wanlass

Pacote: 13 e 10.

Principles of Accounting; 5 ed.

1.371 paginas

A. Douglas Hillman, Richard Kochanek e Isaac Reynolds

Pacote: 9, 11, 17, 15, 3, 4, 13 IBM, 13 Mac, 6, 18, 12, 7, 5, 8, 14 e 19

Financial Accounting: An Introduction to Concepts, Methods and Uses, 6 ed.

850 páginas

Clyde P. Stickney, Roman L. Weil e Sidney Davidson

Pacote: 9, 3, 4, 15, 17, 5 e 19.

Financial Accounting: An Introduction to Decision Making

840 paginas

Thomas J. Beirne e Henry Dauderis

Pacote: 11, 9, 4, 15, 17, 5, 7, 13, 12 e 19.

Financial Accounting: An Introduction, $6 \mathrm{~cd}$.

805 paginas

Paul Walgenbach e Ernest. Hanson

Pacote: 6, 9, 11, 5, 4, 15, 16, 1, 18, 12, 13 IBM, 13 Mac, 7, 8 e 19.

Mmanagerial Accounting - An introduction to Concepts, Methods and Uses, 4 ed.

950 páginas

Michel W. Maher, Clyde P. Stickney, Roman L. Weil e Sidney Davidson

Pacote: 6, 5, 13, 9, 4, 3, 11, 15, 1 e 19.

Management Accounting

850 paginas

J. Edward Ketz, Terry L. Campbell e Sidney J. Baxendale

Pacote: 6, 13, 7, 12, 5, 1, 9, 11, 3, 4, 15 e 19.

Financial Accouting With Lotus 1-2-3: Text and Models

484 paginas

Euqene F. Brighan e Robert Knechel

Pacote: 9 e 19

Advanced Accounting: Concepts and Practice; 4 ed.

1.250 páginas

Arnold J.. Pahler e Joseph E. Mori

Pacote: 11, 15, 17, 12, 1, 13 IBM, 13 Mac, 5, 4 e 19.

Auditing 2 ed.

1.033 paginas - Dan M. Guy, C. Wayne Alderman e Alan J. Winters

Pacote: 11, 9, 5, 6 e 19.

Using IBM Microcomputers In Business: Decision Making With Lotus 1-2-3 and dBase III Plus 700 paginas

Pacote: 9, 3, 4, 1, 13, e 19.

17 Organizações Profissionais e suas publicações

17.1 Publicações dos Professores de Contabilidade nos Periódico. 
Os dois principais periódicos contábeis nos Estados Unidos The Accounting Review (desde 1926) e Journal of Accounting Research (desde 1963)

Alem desses dois periódicos há uma lista de pelo menos 18 outros alternativos voltados para a área acadêmica contábil (os numeras entre parênteses significam o primeiro ano de publicação) Abacus (1965) Accounting Historian's Journal (1974), Accounting Horizons (1987) Acccunting Organization and Society (1976), Advances in Accounting (1984), Advances in International Accounting (1987), Advanced in

Public Interest Accounting (1986), Auditing A Journal of Practice \& Theory (1981), Contemporary Accounting Research (1984), International Journal of Accounting Education and Research (1965), Issues in Accounting Education (1983), journal of Accounting and Economics (1979), Journal ot Accounting Education(1983), Journal of Accounting Ziterature (1982), Journal ot Accoufltiflg and PubliC Policy (1982), Journal of Costs Analysis (1984), Research in Govermental and Nonprofit Accounting (1985).

Os artigos são publicados quase na sua totalidade por professores da área contábil. Conforme levantamento realizado por Ettedge e Wing '(52), quase 10\% do total de professores na área contábil nos Estados Unidos, a cada ano, escreve artigos para os periódicos acima relacionados, conforme tabela abaixo:

\begin{tabular}{|c|c|c|c|c|}
\hline Ano & Total de Artigos & Total de Autores & $\begin{array}{c}\text { Artigos } \\
\text { Total de Professores }\end{array}$ & $\begin{array}{c}\text { Autores } \\
\text { Total de Professores }\end{array}$ \\
\hline & & & & \\
1978 & 196 & 276 & $3,5 \%$ & $5,2 \%$ \\
1979 & 188 & 272 & $3,3 \%$ & $4,8 \%$ \\
1980 & 174 & 261 & $2,9 \%$ & $4,4 \%$ \\
1981 & 204 & 304 & $3,3 \%$ & $4,9 \%$ \\
1982 & 224 & 359 & $3,6 \%$ & $5,8 \%$ \\
1983 & 277 & 415 & $4,4 \%$ & $6,6 \%$ \\
1984 & 321 & 522 & $5,1 \%$ & $8,3 \%$ \\
1985 & 337 & 570 & $5,6 \%$ & $9,5 \%$ \\
1986 & 351 & 571 & $5,7 \%$ & $12,0 \%$ \\
1987 & 428 & 736 & $7,0 \%$ & $9,4 \%$ \\
1988 & 357 & 598 & $5,6 \%$ & \\
& & & & \\
\hline
\end{tabular}

Um dado importante que se detecta na tabela acima e a crescente ênfase que se da para os artigos em co-autoria, aumentando o percentual de autores numa proporção maior que o percentual dos artigos escritos. De fato, ha uma valorização maior dos artigos escritos em co-autoria do que dos artigos individuais. também se observa que estas co-autorias são de professores de diferentes instituições, o que vem engrandecer mais ainda o trabalho escrito.

\subsection{As Organizações e as suas Publicações}

Caderno de Estudos n07, São Paulo, FIPECAFI - Outubro/1992 
A seguir apresentamos uma lista das principais organizações profissionais na área contabilidade financeira e suas publicações periódicas:

\section{American Accounting Association}

5717 Bassie Drive, Barasota, F1 34233 - Tel. 813/921-7747

- The Accounting Review

- Accounting Horizons

- Accounting Education

- Accounting Education News

American Association of Hispanic CPAs

1414 Metropolitan Avenue, Bronx, NY 10462 - Tel: 212/823-6144

- La Cuenta

\section{American Institute of Certified Public Accountants}

1211 Avenue of the Americas, New York, NY 10036 - Tel. 212/575-6200

- The Journal of Accountancy

- The Tax Adviser

- The CPA Latter

- The Practicing CPA

- CPA Client Bulletin

- CPA Client Tax Letter

American Society of Women Accountants

35 Esat Wacker Drive - Suite 1068, Chicago, L 60601 - Tel. 312/726-9030

- The Woman CPA

- The Coordinator

American Woman's society of Certified public Accountants

401 N. Michigan Ave., Chicago, IL 60611 - Tel. 312/644-6610

- National News

- $\quad$ The Woman CPA

Association of Government Accountants

2200 Mount Vermont Avenue, Alexandria, VA 22301 - Tel. 703/684-6931

- Government Accountants Journal

- FOCUS

- Employment Flash

- Government Financial Management Topics

EDP Auditors Association

455 E. Kehoe Blvd., Suite 106, P.O. Box 88180. Carol Stream, XL

60188 - Tel. 708/682-1200

- $\quad$ The EDP Auditor Journal

- $\quad$ The Global Communiqué

Financial Executives Institute

10 Madison Avenue, Morristown NJ 07960 - Tel 201/898-4600

- Financial Executive

Healthcare Financial Management Association 
Two Westbrook Corporate Center - Suite 700, Westchester, IL 60154 - Tel: 708/5319600

- $\quad$ Mealthcare Financial Management

- Patient Accounts

- CFO Forum Voice

- Notes From National

Institute of Internal Auditors

249 Maitland Avenue, Altamonte Springs, FL 32701-4201

Tel: $407 / 830-7600$

- Internal Auditor

- IIA Today

- Pistas de Auditoria

- The Educator

Incarnation Association for Financial Planning

The concourse Parkway - suite 800, Atlanta, GA 30328

Tel. 404/395-1605

- Financial Planning Magazine

- Financial Planning News

National Association of Accountants

10 Paragon Drive, Montvale, NJ 07645-1760 - Tel: 800/638-4427

- Management Accounting

National Association of Black Accountants

900 Second Street, NE, Suite 205, Washington, DC 20002

Tel: 202/682-022

- Spectrum

- News Plus

- Student News Plus

National Society of Public Accountants

1010 N. Fairfax Street, Alexandria, VA 22314 - Tel. 703/549-6400

- National Public Accountant

- NSPA Washington Reporter

- $\quad$ State Regulatory Alert

New York State Society of CPA

200 Park Avenue, New York, NY 10166-0010 - Tel. 212/973-8300

- The CPA Journal

- Carreer Opportunities Handbook

Texas Society of CPAs

1421 W. Mockingbird, Suite 100, Dallas, TX 75247-4957

Tel: 214/689-600

- Today's CPA 
- Capitol Intrest

\section{Centro de Desenvolvimento de Pequenos Negócios}

É comum observar anexo as Business Schools, centros de desenvolvimento de pequenos negócios patrocinados pelas universidades americanas. $\mathrm{Na}$ verdade, os recursos para a manutenção desta atividade vêm do governo federal, do governo estadual, da comunidade acadêmica e do setor privado, no sentido de fortalecer as pequenas empresas e estimular as novas.

O objetivo geral é melhorar a qualidade gerencial e operacional das pequenas empresas e estimular a expansão dos pequenos negócios existentes, bem como estimular a iniciativa de novos negócios. Isto e alcançado através de aconselhamento (consultoria), treinamento e divulgação de informação para os proprietários dos negócios ou para os futuros proprietários.

O aconselhamento consiste em conversas individuais com os proprietários de pequenos negócios (ou futuro proprietário) em qualquer área ou problema. O treinamento consiste em divulgação da informação para grupos de proprietários de pequenos negócios em todas as áreas através de cursos, seminários e conferencias.

Normalmente, estes centros são departamentalizados para atender interesses mais especificas. Ë comum encontrar divisões espeCifiCaS para a mulher empresaria, para exportação (como fazer e como obter recursos), para prestações de serviços específicos como de Contabilidade, Leis, Negócios. Pesquisas etc.

Por exemplo, os servlços de contabilidade abranqem: Implantação de sistemas Contábeis; assistência em planilhas e sistemas de registros computadorizados: aconselhamento em administração financeira; preparação de declaração de impostos; preparação das Demonstrações financeiras e solicitações de empréstimos. assistência na escrituração Contábil; Treinamento e formação em administração financeira, contabilidade e escrituração, controle interno etc.

Só para se ter uma idéia de um caso especifico. a universidade de Connecticut (48) desenvolveu o seu Centro de Pequenos Negócios num programa piloto em 1978, sendo o 19ํㅜ estado a ter seu projeto aprovado em 1980 pelo Centro de Desenvolvimento de Pequenos Negócios do Congresso Americano. Hoje, o centro desta universidade inclui 11 escritores satélites e três faculdades/uniVersidades envolvidas no projeto. Nesta ultima década, este centro atendeu mais de 14.000 casos de aconselhamentos e alcançou em torno de 35.000 clientes em 1.200 programas de treinamento oferecidos. Só em 1990 foram oferecidos 179 programas de treinamento, totalizando 26.700 horas de treinamento, com mais de 5.500 participantes.

Cursos diversificados são oferecidos de maneira geral nos diversos centros que existem naquele pais. Só para exemplificar, a Universidade do Havaí (49) ofereceu os seguintes cursos no verão de 1991 (alem dos cursos de outono e primavera): Métodos de Avaliação Imobiliária; Matemática financeira/Capitalização Começando um Negocio no Havaí: Primeiros Passos, Noções de Computador para Negócios Contabilidade Básica para Empresários; Leis em Negócios: o que cada Proprietário de Pequenos Negócios deve saber; Realidades em Marketing para a década de 90; Exigências Legais para um Pequeno Negocio; Pré-licença para corretores Imobiliários Importação de porcas e parafusos; Fundamentos de Plantas e Projetos - Interpretação e Aspectos Comerciais; Estimativas de Construções; A Arte de Delegar; Técnicas ousadas para o Novo ou o Futuro Gerente; Humor no Local de Trabalho; Tratando dificuldades comportamentais Compensações Trabalhistas; Pessoas administrando com sucesso; Investimentos e impostos; e diversos outros cursos principalmente na área imobiliária.

\section{Congressos e Eventos}


Há dezenas (53) de eventos (congressos/encontros) que unem professores/estudantes e outros interessados na educação contábil nos Estados Unidos. Diversas universidades e associações de classe estão patrocinando estes eventos.

A entidade que mais patrocina tais eventos e a Americam Accounting Association (AAA) que só para 1992 programou os seguintes encontros

- $\quad$ Encontro Regional de Ohio de 1ํa 2 de maio - Dublin, Ohio;

- Encontro Regional do Mid - Atlantic, de 1ํa 4 de abril - Pittsburgh PA,

- Encontro Regional do Midwest, de 16 a 13 de abril - Indianápolis,

- Encontro Regional do Southeast, de 23 a 25 de abril - Charlotte, NC

- $\quad$ Encontro Regional do Southwest, de 4 a 7 de março - San Antonio, TX;

- $\quad$ Encontro Regional do Northeast, de 23 a 25 de abril - Portland, ME;

- $\quad$ Encontro Regional do Western, de 30/4 a 2 de maio - San Jose, CA;

- $\quad$ Conferência em Pesquisa Contábil, 19-20 de novembro, Oklahoma:

- Conferência Anual em Pesquisa da Contabilidade Gerencial, 9 a 13 de outubro - Albuquerque, New México;

- $\quad$ Encontro Anual da AAA, de 9-12 de agosto em Washington DC;

- Conferência sobre Inovação de Métodos de Ensino na Contabilidade Gerencial, 20-21 de março Houston, TX;

A AAA programou ainda para 1992 a Sétima Conferencia Internacional do Educador Contábil, de 8 a 10 de outubro em Washington, DC. Esta conferência foi realizada pela primeira vez em 1962 nos Estados Unidos, na Inglaterra (1967), na Austrália (1972), na Alemanha (1977), no México (1982) e no Japão (1987). Depois de trinta anos ela voltou para os Estados Unidos debatendo-se "A Educação Contábil para o século XXI: Desafios Globais".

Em nível internacional a AAA patrocina a Conferencia Acadêmica/Contábil do Atlântico Norte, onde se discute com lideres acadêmicos da Europa e Canadá problemas relativos à pesquisa contábil, normalização, ensino etc.

\section{Ranking dos Departamentos de Contabilidade}

O principal método utilizado nos Estados Unidos para avaliar a qualidade acadêmica dos Departamentos de Contabilidade tem sido conforme as contribuições que o corpo docente e os cursos de doutorado tem proporcionado em termos de publicações nos períodos contábeis. Há também levantamentos mais antigos considerando a percepção tanto dos educadores como dos profissionais para avaliar as melhores instituições (estes levantamentos não são considerados ideais para avaliar os departamento). No que tange aos programas MBA, a principal classificação e com base no salário inicial dos seus graduados.

À classificação dos Departamentos de Contabilidade e.m função da qualidade acadêmica é importante para fornecer informações úteis para diversos grupos, incluindo estudantes interessados e fazer um doutoramento em Contabilidade, aos próprios professores recém -graduados no doutoramento, que estão 
buscando uma posição acadêmica nas universidades que estão recrutando docentes, a doadores interessados em fornecer contribuições para os cursos de melhor qualidade e o próprio departamento, que avaliara o seu desempenho academio e a qualidade do seu curso.

Interessante trabalho foi publicado recentemente pelo periódico Issues in Accounting Education, (51) onde o estudo considera as publicações de 13 periódicos na área acadêmica - contábil considerado mais importantes, num período de 12 anos (1979 - 1990). As escolas são classificadas de acordo com a representação dos seus docentes e dos seus doutores em Contabilidade nestas publicações.

Neste período foram publicados nestes 13 períodos 1392 artigos, sendo que 1179 se referem a acadêmicos na área contábil (deste total apenas 22 não possuíam o titulo de doutor em Contabilidade)

A representação no quadro 'de publicações considerando docentes por instituição, evidencia o seguinte ranking

\begin{tabular}{|clc|}
\hline Ranking & Instituição & № Docentes-Publicações \\
\hline 01 & Chicago & 44 \\
02 & Stanford & 40 \\
03 & Minnesota & 34 \\
04 & Texas & 33 \\
05 & U. Washington & 32 \\
06 & Pennsylvania & 27 \\
07 & lowa & 26 \\
08 & Southern California & 26 \\
09 & Illinois & 25 \\
10 & British Columbia & 24 \\
11 & Berkeley, Cornell e Florida: & \\
14 & Carnegie Mellon, Michigan, Northwestern e Pittsburgh \\
20 & Arizona State e Ohio State: & \\
\end{tabular}

A representação no quadro de publicações considerando a Instituição onde os autores dos trabalhos obtiveram titulo de doutor em Contabilidade evidencia o seguinte ranking:

\begin{tabular}{|clc|}
\hline Ranking & Instituição & № Autores -Publicações \\
\hline 01 & Illinois & 95 \\
02 & Chicago & 93 \\
03 & Stanford & 51 \\
04 & Carnegie Mellon & 57 \\
05 & Ohio State & 56 \\
06 & Berkeley & 55 \\
07 & Minnesota & 55 \\
07 & Texas & 54 \\
\hline
\end{tabular}

Caderno de Estudos n07, São Paulo, FIPECAFI - Outubro/1992 


\begin{tabular}{|lll|}
\hline 09 & Michigan States & 44 \\
10 & Michigan & 42 \\
11 & U. Washington; & \\
12 & Cornell: \\
13 & Rochester; \\
14 & lowa; \\
15 & Indiana; \\
16 & Northwestern; \\
17 & Florida; \\
18 & Wisconsin \\
19 & Penn State; \\
20 & UCLA \\
\hline
\end{tabular}

\section{Bibliografia Consultada}

01. Anthony, Robert.; Reece, James S. 8'. ed. Irwin Accounting: test and cases.

02. Cordon Robert A., Howell James E. Higher Education form business. New York: Columbia University Press, 1059.

03. Pierson Frank C. et al. The education of American businessmen. Mew York: McGraw-Hill, 1959.

04. Roy Robert H., McNeill, James H., Horizons for professions. New York: American Institute of Certified Public Accountants, 1967.

05. Williams, Doyle Z. Accounting education: a statistical. survey. New York: American Institute of Certified Public Accountants, 1989.

06. Accounting Education - Statistical Survey / 1987-1988. New York: American Institute of Certified Public Accountants, 1989.

07. Perspectives on Education: Capabilities for Success in the Accounting Profession. Brochure by Arthur Andersen \& Co., Arthur Young, Coopers \& Lybrand, Deloitte Haskins \& Sells, Ernest: \& Whinney, Peat Marvick Main \& Co., Prince Waterhouse and Touche Ross, April 1989.

08. Future Accounting Education: Preparing for The Expanding Profession. Special Report of the American Accounting Association. Committee on the Future Structure, Content, and Scope of Accounting education published. Issues in Accounting Education, 1986.

09 Education Requirements for Entry Into the Accounting Profession: A Statement of AICPA Policies 2d ed., rev. New York: American Institute of Certified Public Accountants, 1988.

10. Mclnnes, Mary Sanders, Beatrice. The supply of accounting graduates and the darned for public Accoutinting recruits. New York.: American Institute of Certified Public Accountants, 1988. 
11. National Center for Education Statistics, Digest of Education Statistics 1987 Washington, DC.: US Governmen: PrIntIng Office, 1987.

12. Hasselback, James R. Accounting faculty directory. Englewood cliffs, N.J.: Prentice-Hall, 1988.

13. Leider, Anna J. Scholarships for international students Octameron Press, Alexandria, VAS: 1989.

14. Financial Resources For International Study Peterson's Guides. Princeton, : 1990.

15. Under Pressure, Business Schools Devise Changes. The Wall Street Journal, April 23, 1991.

16. Surveys Show Professors Salaries, Journal World, Lawyerlike, Kansas, May 14,1991.

17. Salary Expectations For Entering Accountants. Management Accounting Campus Report - NAA Fall 1990.

18. The Job Market Tightens Up. Managing Your Carreer. The wall Street Journal, Spring 1991.

19. Seventh Annual. Survey of Business School Computer Usage. The Anderson Graduate School of Management, UCLA, September de 1990.

20. The 1990 EDUCOM. USCSurvey at Desktop Computing. Center for Scholarly Technology at the University of Southern California outubro de 1990.

21. The Newsletter for Educational Software Users. Addison-Wesley 8enjamin Cummings, v.4, nำ1, winter 1991.

22. Blagioni, Louis F. Accounting principles. Computer- Assisted - Practice SET/DASH II for IBM-PC. New York: Random House, college Software.

23. HBJ - Harcourt Brace Jovanovich college department. 1250 Sixty. Avenue, San Diego - California.

24. Business Week. Dec. 9. 1991, p. T. McGraw-Hill.

25. Cost of Living index - American Chamber of Commerce Researchers Association Inter-city. Third quarter-1990. Managing Your Careers. The Wall Street. Journal, spring 1991.

26. Arthur Andersen and Andersen Consulting increase Support to Faculty Fellowship and Enhance Computing. Accounting Channels, The University of Kansas, nov. 1991.

27 The Nations Laqest Employers. Human Resource Executlve r aqaz1ne. Manaqing Your Carrer. The Wall Street curnai, Spr ng 1991.

28. A Guide Undergraduate Students. The School of Business, Accounting Division. Universities de Kansas, 1991.

29. The (University of Connecticut. EMBA - Executive Master to Business Administration. Framington, Connecticut.

30. Walden University. Institute For Advanced Studies, 1991/92. Minneapolis, Minnesota.

31. Distance Education: Uses Electronic Links. The Wall Street Journal, 13/09/91, p.1 e 6.

32. Graduate Programs - School of Accountancy. The University of Mississippi, University, MS - 38677. 
33. Truces - Companies Crack Down of Dishonesty. The Wall Street Journal. The College Editor of the National Business Employment: Weekly. Managinq Your Carreer patrocinado pela Honda no primeiro semestre de 1991.

34. Bartlett, Anita Wollison. How do you fell about your major? Hasselback, James R., comp. Managing Your Carreer, Spring 1991.

35. Accounting Faculty Directory. Florida State University. Englewood Cliffs, N.J.: Prentice Hall.

36. Chasteen, L.R., Flaherty, Conner, M.O. Intermediate accounting Flamholtz Diana 2. ed., Random House, 1989.

37. Diamond, Michael A.; Flamholtz, Eric G.; Financial accounting Flamholtz Diana Troik 2. ed. Kent: PWS

38. Jobs in Accounting. Person/Wolinsky CPA Review, New York.

39. Strategic Planning for the CPA Exam. Person/Wolinsky CPA Review Courses, New York

40. Rayburn, Judy. Evidence on the Information Content of Supplemental Oil and Gas Reserve Disclosure in The Petroleum Industry The University of Minnesota, Jan. 1991.

41. HORNGREN,Charles T., Foster, George. Cost Accounting: a managerial emphasis. . ed. New Jersey: Prentice Hall, 1991.

42. CUSHING, B., Romney, M. Accounting information systems, 5. ed. New York: Addison-Wesley.

43. The Expert-Ease of Expert systems. Camagazine, p.5O, Ago. 1986.

44. Newquist, Harvey. citado em computerworld em 13 de janeiro de 1986.

45. Feigenbaun Edward, McCorduck, Pamela, The Fifth Generation New York: Signet Books, 1984.

46. A Guide For Undergraduate students; Kansas University.

47. Ostling, Richard N. Big Chill on Campus. Time, 3 de fevereiro de 1992, p. 61-63.

48. Connecticut Small Business Development Center. Partners for Small Business. Annual Report 19891990.

49. The University of Hawaii at Manoa.

Small Business Management Program, College of Continuing Education and Community Service.

50. The Trouble with MBAs. Fortune, 29 jul. 1991, p.75.

51. Mitternaier, Linda J. Representation on the editorial boards of academic accounting journals: an analysis os accounting faculties an doctoral programs. Issues in Accounting Education, v. 6, n.2, Fall 1991.

52. ETTREDGE, Michael, WONG-ON-WING, Bernard. Publication opportunies un accounting research journals: 1970-1988. Issues In Accounting Education, V. 6, n. 2, Fall 1991.

53. AIR - Accounting Instructors' Report. Boston: Hounqhton Mifflin, V.X, n. 01, spring 1991. 
54. SMOLOWE, Jill. The pursuit of excellence. Time, Apr. 13 1992, p. 59 e 60.

55. McCarrol, Thomas. Accounting Who's counting Time, Apr. 13 1992, 54-58.

56. ELSON, John. Campus of future. Time, Apr. 13 1992, p.54-58

57. KSCPA Accounting Educators Conference. Does introductory Accounting News Radical Surgery? he University of Kansas, :an. 23, 592.

58. Mock, Theodore J., Pincus, Karen V. ANDRE, James M. A system approach to accounting curriculum development. Issues In Accounting Education, v.6, n.2, p. 1.78 - 192, Outono de 1991, American Accounting Association.

\section{Anexo 01}

\section{A Crise de confiança nas Empresas de Auditoria nos EUA.}

Quando ha citações as empresas de auditoria nos EUA, faz-se referencia direta aos contadores. Por exemplo, no índice de revista T:me (13 de abril de 1992 - vol. 139, N 15), pagina 3, há a seguinte

chamada: "Contadores sob assedio: À profissão enfrenta a mais seria crise de responsabilidade legal na sua história." Na pagina 48 em diante (55) , na secção negócios, com o titulo Contabilldade, destaca-se a investigação pública e os enormes gastos com demandas legais que a profissão contábil vem sofrendo em virtude da sua atuação na auditorla principalmente em instituições de empréstimos e poupanças.

Um dos casos bastante conhecido ocorrido em meados da década passada e o da Miniscribe, uma empresa do Cobrado produtora de peças para computador, cujas Demonstrações Financeiras evidenciavam uma situação vigorosa e promissora. Todavia, na investigação foram descobertas fraudes administrativas onde eram expedidos caixas com tijolos embalados como se fosse disk drives e computadores sendo vendidos. Além das acusações sobre os administradores da empresa, a demanda também pesa sobre a auditoria julgada imperfeita. No ultimo fevereiro 1992 a Coopers \& Lybrand, responsável pela auditoria, foi condenada a pagar U\$ 200 milhões por prejuízos causados, na mais pesada punição contra uma empresa de auditoria.

Atualmente há diversas outras empresas de auditoria que foram levadas a corte. Há aproximadamente 4.000 ações judiciais de responsabilidade (pleitos) envolvendo contadores americanos montantes este considerado o dobro de 1985. Estas ações abrangem mais de U\$\$ 15 de prejuízos. Só no ano de 1991 as "seis grandes" empresas de auditoria pagaram mais de U\$ 300 milhões na liquidação destas questões. Ao mesmo tempo em que acontece isto, o seguro para as empresas de auditoria tem aumentado consideraVelmente, dado risco iminente de litígios.

Aproximadamente dois terços destes litígios se originaram da arca de poupança e empréstimos. As ações enfrentadas vêm na sua maioria de investidores e órgãos reguladores do governo, incluindo a Federal Deposit Insurance Corporation. 
A responsabilidade financeira dos contadores nos casos de empresa de poupança e empréstimos pode exceder U\$\$ 9 bilhões. No inicio de abril de 1992, a Ernest \& Young concordou em pagar U\$\$ 63 milhões para liquidar uma causa cuja negligência teria ajudado Charles Keating Jr. a enganar 23 mil investidores através da Lincon Savings \& Loan. Este acerto veio duas semanas após a maior empresa de auditoria dos EUA, Arthur Andersen, ter pagado U\$\$ 22 milhões por pedido de indenização por fraude na mesma área de poupança e empréstimo.

É lógico que "as grandes seis" empresas de auditoria que faturam nos EUA um quarto de U\$\$ 46 bilhões da receita total no setor tem suas justificativas para cada caso. O que queremos ressaltar nestas Observações e a preocupação que a educação contábil deve ter com ética. Observamos que ha uma ênfase cada vez maior no ensino da Contabilidade nos EUA com esta área tão delicada da profissão.

\section{Anexo 2}

\section{Um Sistema de abordagem de Desenvolvimento de Currículo para a Contabilidade}

Por ocasião da nossa participação na conferência para educadores contábeis, com o tema "A Contabilidade introdutória precisa de uma cirurgia radical ?" (57) tivemos contato com a palestrista professora Karen V. Pincus, que falou sobre "A seqüência da Contabilidade introdutória na The University of Souther Califórnia (USC)". Esta professora foi responsável pela primeira experiência de uma mudança radical no currículo de Contabilidade nos Estados Unidos nos últimos tempos. Muitas outras universidades americanas estão atualmente na fase de mudanças em conjunto (e com fundos) da Accounting Education Change Comission, comissão esta que foi constituída especificamente para mudar ou aperfeiçoar a educação contábil nos EUA.

A professora Karen passou então a nos fornecer algumas informações e experlências relevantes obtidas no processo de implementação do novo currículo na Universidade do Sul da Califórnia (USC) e dos frutos colhidos decorrentes da mudança. Em conjunto com outros dois professores desta mesma universidade que participaram da mudança curricular, Karen V. Pincus publicou esta experiência para a comunidade contábil americana através do Issue in Accounting Education (58). O novo currículo começou a ser elaborado em 1987 dentro de uma nova sistemática de abordagem, sendo desenvolvido em quatro fases distintas: planejamento geral do novo projeto de currículo, planejamento e analise do currículo (análise e planejamento do sistema), concepção [desenho] do sistema e avaliação e implementação do sistema. Assim, a escola de Contabilidade da USC lançou o "Projeto Curricular para o Ano 2,000" financiado com recursos da Coopers \& Librand Foundation durante três anos.

Segundo os professores responsáveis pela mudança curricular dos cursos de Contabilidade da USC, o planejamento do currículo e a concepção de estratégias instrucionaiS da maioria das faculdades e universidades reporta-sê a períodos anteriores a segunda guerra mundial. Mesmos os modelos de currículo mais modernos, muitas vezes, têm como base acréscimos ou emendas, mantendo-se pontos discutíveis no modelo tradicional e apenas mudando alguns tópicos. Uma abordagem na base zero é realizada por estes professores, avaliando-se novos cursos e programas propostas decorrentes de metas e objetivos traçados.

Muitas pessoas defendem o ponto de vista de que a educação contábil foi congelada na forma de um grande iceberg algumas décadas atrás e que somente agora esta começando a derreter. Novas abordagens na educação contábil, no processo de ensino, nos métodos de ensino São reivindicados tanto por acadêmicos 
quanto por profissionais. Todavia, ainda que haja quase unanimidade nesta colocação, a pergunta que surge é: "Como realizar tais mudanças"?.

No caso da USC optou-se em interromper as mudanças curriculares por acréscimos (emendas), já que isto trazia frustrações com as limitações do currículo atual. Apos muitos debates começou-se o projeto de redesenhar um novo currículo. O processo incluiu consultas junto a professores e alunos de doutoramento da escola de Educação e revisão na literatura educacional, bem como textos sobre concepção de sistemas de informações. A literatura da área de educação ajudou a definir as opções; os textos de sistemas ajudaram a identificar a definição dos passos e procedimentos que são apropriados para ajudar a administrar o processo de mudança.

E interessante observar que a concepção do currículo foi reconhecida como sendo similar à concepção de um complexo sistema de informação. Primeiro, o currículo e um processo de informação com o objetivo de eficientemente comunicar relevantes informações para os usuários identificáveis (estudantes) . Segundo, currículos são sistemas altamente complexos que devem antecipar uma variedade de inputs e devem levar vantagens (se antecipar) ás rápidas mudanças tecnológicas. Dentro deste enfoque, começou-se a trabalhar em cima das quatro fases já referidas.

Na tabela 1, a seguir, se fazemos um sumário das quatro fases dos elementos da concepção do sistema de um novo currículo de Contabilidade realizado por um grupo de trabalho da Universidade do Sul da Califórnia.

Tabela 1 Elementos do projeto de Sistemas da USC - Quadro fases

\begin{tabular}{|c|c|c|c|}
\hline \multicolumn{4}{|c|}{ (Fase Planejamento Geral 119871988) } \\
\hline $\begin{array}{c}\text { Grupo de } \\
\text { trabalho/comitê }\end{array}$ & $\begin{array}{l}\text { Atividade de Grupo de } \\
\text { Trabalho e do comitê }\end{array}$ & $\begin{array}{l}\text { Resultados } \\
\text { obtidos }\end{array}$ & 1 \\
\hline $\begin{array}{l}\text { Grupo de } \\
\text { Trabalho/Currículo } \\
\text { Do Graduação }\end{array}$ & $\begin{array}{l}\text { Pesquisa junto á docentes, alunos atuais e ex-alunos } \\
\text { referentes às mudanças desejadas no currículo do graduado. } \\
\text { Estudo da exeqüibilidade da revisão disciplinas/contábeis }\end{array}$ & $\begin{array}{l}\text { Relatório Pesquisa } \\
\text { Proposta de Fundos }\end{array}$ & \\
\hline $\begin{array}{l}\text { Comitê de apreciação do } \\
\text { curso de } 5 \text { anos }\end{array}$ & $\begin{array}{l}\text { Segunda apreciação para o curso de } 5 \text { anos da Escola de } \\
\text { Contabilidade }\end{array}$ & Apreciação curso 5 anos & \\
\hline & $\begin{array}{l}\text { Fase 2: Análise e Planejamento do Currículo } \\
\qquad(1988-1989)\end{array}$ & & \\
\hline $\begin{array}{lr}\text { Grupo de } & \text { Trabalho } \\
\text { APC...Análise } & \text { e } \\
\text { planejamento } & \end{array}$ & $\begin{array}{l}\text { Preparação do plano geral e do projeto conceitual para o } \\
\text { projeto e desenvolvimento do currículo. Consideração do } \\
\text { projeto e da reserva de recursos e a obtenção de recursos. } \\
\text { Preparação dos Relatórios sobre os progressos. }\end{array}$ & $\begin{array}{lr}\text { Avaliação } & \text { das } \\
\text { necessidades } & \text { Metas a } \\
\text { serem obtidas. } & \text { Relatórios } \\
\text { avaliando o } & \text { progresso } \\
\text { obtido } & \end{array}$ & $\begin{array}{l}2 \\
o \\
F \\
a \\
\mathrm{~s} \\
\mathrm{e} \\
\end{array}$ \\
\hline & & & \\
\hline
\end{tabular}




\begin{tabular}{|c|c|c|c|}
\hline $\begin{array}{l}\text { Grupo de Trabalho de } \\
\text { Pesquisa }\end{array}$ & $\begin{array}{l}\text { Pesquisa sobre aspectos atuais e futuros da pedagogia e } \\
\text { tecnologia educacional. 'Consideração sobre as formas de } \\
\text { incorporação de tais pedagogia e tecnologia dentro do } \\
\text { currículo de uma escola de Contabilidade Apreciação da } \\
\text { literatura existente sobre a educação contábil e as previsões } \\
\text { de mercado das demandas esperadas pelos estudantes }\end{array}$ & $\begin{array}{l}\text { Apreciação da Pedagogia } \\
\text { Apreciação da Tecnologia } \\
\text { Apreciação do banco de } \\
\text { dados sobre a educação } \\
\text { contábil }\end{array}$ & \\
\hline & Fase 3: Concepção do Sistema (1989-1993) & & \\
\hline $\begin{array}{l}\text { Grupo de Trabalho de } \\
\text { Contabilidade Introdutória } \\
(1989-1991)\end{array}$ & $\begin{array}{l}\text { Desenvolvimento de uma nova seqüência para o um novo } \\
\text { primeiro ano de Contabilidade Introdutória. Propiciar } \\
\text { treinamento dos docentes. Avaliar as atividades de ensino }\end{array}$ & $\begin{array}{l}\text { Conceitos do âmago da } \\
\text { Informação Contábil }\end{array}$ & $\begin{array}{l}3 \\
0 \\
\mathbf{f}\end{array}$ \\
\hline $\begin{array}{l}\text { Grupo de Trabalho do } \\
\text { Segundo Ano (1990-1992) }\end{array}$ & $\begin{array}{l}\text { Desenvolvimento da seqüência de curso para o novo aluno } \\
\text { de primeiro ano. Prover treinamento dos docentes. Avaliar } \\
\text { atividades de ensino... }\end{array}$ & $\begin{array}{|lr|}\text { Julgamento e resolução de } \\
\text { Problemas em } \\
\text { Contabilidade }\end{array}$ & \\
\hline $\begin{array}{l}\text { Grupo de trabalho de } \\
\text { Aplicação Especialização } \\
\text { Ano (1990-1996) }\end{array}$ & $\begin{array}{l}\text { Desenvolvimento da seqüência de curso do chamado aluno } \\
\text { "Senior". Revisão dos cursos de Mestrado em Contabilidade } \\
(5 \text { anos ) Prover treinamento para docentes. Avaliar } \\
\text { atividades de ensino }\end{array}$ & $\begin{array}{l}\text { Cursos de Aplicação } \\
\text { Cursos de Especialização }\end{array}$ & \\
\hline & $\begin{array}{l}\text { Fase 4: Implementação e Avaliação do Sistema } \\
\qquad(1990 \text { - 1996) }\end{array}$ & & \\
\hline $\begin{array}{l}\text { Grupo de Trabalho de } \\
\text { Avaliação }\end{array}$ & Avaliação do novo Sistema de currículo & Relatórios de Avaliação & $\begin{array}{l}4 \\
o \\
\text { f } \\
\text { a } \\
\text { s } \\
\text { e }\end{array}$ \\
\hline
\end{tabular}

O resultado do Planejamento Geral da Anallse e Planejamento do currículo produziu uma nova concepção de programa que tem cinco características básicas. O novo currículo reflete, segundo à crença do grupo que o criou, maior integração das áreas funcionais da Contabilidade e maior integração do desenvolvimento do conhecimento técnico com o desenvolvimento de habilidades que terão significativos benefícios aos estudant5es. As cinco características básicas são:

1. Uma abordagem conceitual voltada para a habilidade (perícia) de maneira analítica para resolver problemas e tomar decisões.

Em resumo, tradicionalmente, os estudantes têm aprendido primeiro as regras (impostos, normas contábeis e de auditoria etc.) para depois considera-las na aplicação dos problemas e questões a medida que for necessário. No novo currículo proposto, as questões e os problemas são focalizados e as aprendizagens para atender as regras ocorrem no esforço de resolver aquelas questões e problemas. A maneira analítica e a habilidade desenvolvida para resolver os problemas e tomar decisões por esta abordagem devem prover uma mais prolongada contribuição para a carreira profissional do estudante que uma abordagem na qual ha concentração de regras técnicas e fatos que estão debaixo de constantes mudanças.

\section{Abordagem Integrativa}

Cada curso ao nível de graduação se relacionara com todas as áreas da Contabilidade (financeira1 gerencial, sistemas, impostos e auditoria) . Por exemplo, um novo curso de Contabilldade Introdutória, quando os estudantes aprendem sobre inventario, considerarão as questões e problemas relativos ao 
nível de inventário a ser mantido, ao método contábil a ser escolhido, aos aspectos fiscais, aos sistemas de controle interno, ao ciclo de armazenamento, para operacionalizar e auditar as demonstrações financeiras.

3. Integração do treinando entre habilidades interpessoais, comunicação, tecnologia, ética e valores relativos a responsabilidade profissional, dentro do curso.

O consenso que predominou no planejamento e analise do currículo foi. que o desenvolvimento de habilidade não deveria ser tratado como compartimentos separados dentro do currículo. Em vez disso, desenvolvimento de habilidades deveria ser inseparável no tratamento das questões a problemas contábeis. Por exemplo, o aluno, para ganhar familiarização com as tecnologias usadas pela Contabilidade deve usar desde o principio do curso o computador. Os problemas de éticas e responsabilidade proflssional serão tratados por ocasião em que os problemas e questões forem sendo desenvolvidos etc.

4. uso das variedades de "ferramentas" e métodos de ensino

Tradicionalmente, na maiorla dos cursos de Contabilidade pratica-se o ensino através de instrutor, com aulas expositivas como método predominante de instrução. o projeto de currículo desenvolvido resultara no uso de ampla variedade de rnétodos de enslno, incluindo uma diversificação maior nos recursos humanos (por exemplo um time de professores em vez de um único), maior variedade no uso de tecnologia de ensino (Vídeo, computador) e mais tempo de aula dedicado a interação maior entre alunos e instrutores (mais uso de casos)

\section{Uma abordagem modular}

os cursos em relação ao novo currículo serão projetados em módulos integrados. Esta abordagem tem a vantagem de aumentar a flexibilidade e propiciar constante atualização, já que serão tratados tudo á base de temas. A seqüência do curso de Contabilidade Introdutória, apos o estudante já ter completado o curso de computação básica e outras exigências, consistira em dois conjuntos de temas em cada semestre. O primeiro semestre começa com uma visão geral do uso da informação contábil para tomada de decisões, terminando com questões contábeis concernentes a resultado e fluxo de caixa. $\mathrm{O}$ segundo semestre começa considerando questões contábeis envolvendo recursos econômicos e termina com considerações de questões contábeis envolvendo capital. Assim serão vistos, no inicio, módulos tais como conceitos de relatórios e avaliação financeira, conceitos para concepção, avaliação e auditagem do sistema de informação financeira, etc.

A mudança curricular exigiu além do suporte financeiro e físico, a disponibilidade de tempo para o grupo de trabalho. Como a principio não ha livros -textos e materiais didáticos disponíveis para atender as mudanças, os docentes tiveram de preparar seu próprio material.

Resistência às mudanças teve de ser administradas, tanto em relação a alguns docentes como também a alunos que entendiam ser adequado o sistema até então em vigor. Muitas reuniões, debates e ate mesmo "retiro" foram necessários. 